\title{
Synthesis of Indeno[1,2-b]benzofurans using TPAB as Highly Efficient and Recoverable Catalyst
}

\author{
Ahmad Poursattar Marjani* ${ }^{*}{ }^{\S}$, Jabbar Khalafy ${ }^{*}$ (iD) and Somayeh Akbarzadeh \\ Department of Organic Chemistry, Faculty of Chemistry, Urmia University, Urmia, Iran. \\ Received 5 February 2019, revised 3 July 2019, accepted 21 July 2019.
}

\begin{abstract}
Herein we report the synthesis of some novel indeno[1,2-b]benzofuran derivatives by reaction of ninhydrin with cyclic 1,3-dicarbonyl compounds including cyclopentane-1,3-dione, cyclohexane-1,3-dione, dimedone, 4,4-dimethylcyclohexane-1,3dione, meldrum's acid, barbituric acid, thiobarbituric acid, 1,3-dimethylbarbituric acid and indane-1,3-dione. We also used tetrapropylammonium bromide (TPAB) as an organocatalyst.
\end{abstract}

KEYWORDS

Cyclic 1,3-dicarbonyl compounds, ninhydrin, indeno[1,2-b]benzofurans, ТРАВ.

\section{Introduction}

The synthesis of indeno[1,2-b]benzofurans through the reaction of ninhydrin with 1,3-diketones, aryl aldehydes and malononitrile has been carried out under different reaction conditions. Numerous types of reagents, like $\mathrm{AcOH}_{1}{ }^{1} \mathrm{I}_{2} / \mathrm{MeOH},{ }^{2}$ $\mathrm{BF}_{3}-\mathrm{OEt}_{2},{ }^{3} \mathrm{EtOH} / \mathrm{US}^{4}$ are known for their catalyzing effect on this reaction. In spite of acceptable results obtained from the abovementioned methods, their usage is limited by some disadvantages such as high cost, low yields of product, high reaction temperatures and the use of some less than desirable solvents.

The indeno[1,2- $b]$ benzofurans are important heterocyclic compounds due to their wide range of pharmaceutical and biological activities, such as their anti-microbial, anti-oxidant, analgesic and anti-inflammatory properties. ${ }^{1,5}$

Tetrapropylammonium bromide (TPAB) is a readily available, and inexpensive chemical and one of the most commonly utilized phase-transfer catalysts (PTC) with numerous applications in diverse catalytic processes, including for instance in the synthesis of ZSM-type zeolites. ${ }^{6}$

Following our previous research work involving the synthesis of novel heterocyclic compounds, ${ }^{7}$ we report here the production of some new indeno[ $[1,2-b]$ benzofuran derivatives in excellent yield and relatively short reaction times, through the reaction of ninhydrin with cyclic 1,3-dicarbonyl compounds, using TPAB as a recyclable catalyst.

\section{Experimental}

The chemicals used in the current research were purchased from Acros and Merck companies. FTIR spectra were recorded with a Thermo Nicolet (Nexus 670) instrument. ${ }^{1} \mathrm{H}$ and ${ }^{13} \mathrm{C}$ NMR spectra were recorded on a Bruker spectrometer at 300 and $75 \mathrm{MHz}$ in $\mathrm{CDCl}_{3}$ or DMSO- $d_{6}$ as solvents and using TMS as the internal standard. Mass spectra were recorded on a Varian Matt 311 spectrometer. Melting points were determined with an Electrothermal 9200 apparatus. Elemental analyses were performed using a Leco Analyzer 932.

General Procedure for the Synthesis of Products 3a-i

A mixture of ninhydrin $(\mathbf{1}, 1 \mathrm{mmol})$ and cyclic 1,3-dicarbonyl

* To whom correspondence should be addressed.

E-mail: a.poursattar@gmail.com / a.poursattar@urmia.ac.ir compounds $2 \mathbf{a}-\mathbf{i}(1 \mathrm{mmol})$ was heated in the presence of TPAB $(20 \mathrm{~mol} \%)$ in dichloromethane $(2 \mathrm{~mL})$ under reflux for an appropriate time (Scheme 1). The reaction progress was investigated by TLC using $\mathrm{CH}_{2} \mathrm{Cl}_{2}$ /hexane/methanol, 15:15:1. After completion of the reaction, the solvent was removed under reduced pressure and the obtained precipitate was filtered and washed with $\mathrm{H}_{2} \mathrm{O} / \mathrm{EtOH}(1: 2)$, resulting to the desired products $3 \mathbf{a}-\mathbf{i}$ in good yields of $87-98 \%$.

\section{Recovery of TPAB}

In the separation of products $\mathbf{3 a - i}$, after extraction of filtrate with $\mathrm{CHCl}_{3}$, the aqueous layer was separated and evaporation of water gave TPAB, which may be used for reusability process.

4a,9a-Dihydroxy-2,3,4a,9a-tetrahydrocyclopenta[ $b]$ indeno[2,1d]furan-1,9-dione (3a): This compound was obtained from cyclopentane-1,3-dione, time reaction $26 \mathrm{~min}$, white powder, yield $87 \%$; m.p. $159-161{ }^{\circ} \mathrm{C}$; FT-IR $v_{\max }$ : 3494, 2926, 2563, 1749, 1714, 1604, 1545, 1370, 1291, 1142, 954, 848, 768, 717, 640, 581, 476, $426 \mathrm{~cm}^{-1} ; \delta_{\mathrm{H}}: 7.98(4 \mathrm{H}, \mathrm{bs}, \mathrm{Ar}), 3.61(2 \mathrm{H}, \mathrm{bs}, 2 \times \mathrm{OH}), 2.38(4 \mathrm{H}, \mathrm{bs}$, $\left.2 \times \mathrm{CH}_{2}\right) ; \delta_{\mathrm{C}}: 194.7,191.5,158.6,143.2,142.1,141.3,130.8,127.8$, $126.6,119.3,115.7,72.2,36.1,29.3 ; \mathrm{m} / z: 259[\mathrm{M}+1]^{+}(95), 258[\mathrm{M}]^{+}$ (100), 242 (46), 230 (95), $173(39), 134$ (28), 105 (62), 104 (57), 77 (42), 76 (38). Found: $\mathrm{C}, 65.12 ; \mathrm{H}, 3.90 \%$. Calc. for $\mathrm{C}_{14} \mathrm{H}_{10} \mathrm{O}_{5}(258)$; C, 65.29; H, $3.80 \%$.

$4 b, 9 b$-Dihydroxy-6,7,8,9b-tetrahydro- $9 H$-indeno[1,2- $b]$ benzo furan-9,10(4bH)-dione (3b): This compound was obtained from cyclohexane-1,3-dione, time reaction $20 \mathrm{~min}$, yellow needles, yield $93 \%$; m.p. $165-168^{\circ} \mathrm{C}$ [lit., ${ }^{1} 174{ }^{\circ} \mathrm{C}$ ].

4b,9b-Dihydroxy-7,7-dimethyl-6,7,8,9b-tetrahydro-9H-indeno $[1,2-b]$ benzofuran-9,10 $(4 b H)$-dione $(\mathbf{3 c})$ : This compound was obtained from dimedone, time reaction $25 \mathrm{~min}$, white needles, yield $98 \%$; m.p. $198-200{ }^{\circ} \mathrm{C}$ [lit., $\left.{ }^{4} 210{ }^{\circ} \mathrm{C}\right]$.

4b,9b-Dihydroxy-6,6-dimethyl-6,7,8,9b-tetrahydro- $9 H$-indeno[ 1,2-b]benzofuran-9,10(4bH)-dione (3d): This compound was obtained from 4,4-dimethylcyclohexane-1,3-dione, time reaction 25 min, white powder, yield $97 \%$; m.p. 152-154 ${ }^{\circ} \mathrm{C}$; FT-IR $v_{\max }: 3389,3253,3096,2941,2880,2679,2495,2360,1711,1660$, 
<smiles>O=C1c2ccccc2C(=O)C1(O)O</smiles>

1<smiles></smiles>

2a<smiles></smiles>

$2 \mathrm{c}$<smiles>O=C1CC(=O)OC2(CC2)O1</smiles>

$2 \mathrm{e}$<smiles>O=C1CC(=O)NC(=S)C1</smiles>

$2 \mathrm{~g}$<smiles>O=C1CCC(=O)CC1</smiles>

2a-i<smiles>O=C1CCCC(=O)C1</smiles>

2b<smiles></smiles>

2d<smiles>O=C1CC(=O)NC(=O)N1</smiles>

$2 f$<smiles></smiles>

2h

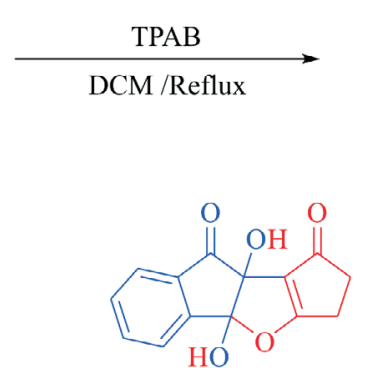

3a, 26 min, $87 \%$<smiles>CC1(C)CC(=O)C2=C(C1)OC1(O)c3ccccc3C(=O)C21O</smiles>

3c, $25 \mathrm{~min}, 98 \%$<smiles>COC1=C2C(=O)OC(C)(C)C(=O)C2(O)C(O)(O)O1</smiles>

3e, $26 \mathrm{~min}, 87 \%$<smiles>CC12Oc3[nH]c(=S)[nH]c(=O)c3C1(O)C(=O)c1ccccc1C2=O</smiles>

3g, 30 min, $92 \%$<smiles>O=C1CCC2=C1C1(O)C(=O)c3ccccc3C1(O)O2</smiles><smiles>O=C1CCCC2=C1C1(O)OC3(O)c4ccccc4C(=O)C3(O)OC21</smiles>

3b, 20 min, $93 \%$<smiles>CC1(C)C2=C3C(=O)CCC1(C)C3C1(O)C(=O)c3ccccc3C1(O)O2</smiles>

3d, $25 \mathrm{~min}, 97 \%$<smiles>O=C1c2ccccc2C(O)(O)C1(O)c1c(O)[nH]c(=O)[nH]c1=O</smiles>

3f, $30 \mathrm{~min}, 91 \%$<smiles>Cn1c2c(c(=O)n(C)c1=O)C1(O)C(=O)c3ccccc3C1(O)O2</smiles>

3h, $30 \mathrm{~min}, 89 \%$<smiles>O=C1CC(=O)c2ccccc21</smiles><smiles></smiles>

3i, $27 \min , 88 \%$

Scheme 1

Synthesis of indeno[1,2-b]benzofurans $3 \mathbf{a}-\mathbf{i}$.

$1609,1469,1392,1330,1294,1263,1178,1158,1066,1006,949,920$, $881,852,778,668,577,520,499,448 \mathrm{~cm}^{-1} ; \delta_{\mathrm{H}}: 7.90-7.88(2 \mathrm{H}, \mathrm{m}, \mathrm{Ar})$, 7.74-7.65 (2H, m, Ar $), 5.51(2 \mathrm{H}, \mathrm{bs}, 2 \times \mathrm{OH}), 2.26\left(2 \mathrm{H}, \mathrm{bs}, \mathrm{CH}_{2}\right), 1.27$ $\left(2 \mathrm{H}, \mathrm{bs}, \mathrm{CH}_{2}\right), 1.03\left(6 \mathrm{H}, \mathrm{s}, 2 \times \mathrm{CH}_{3}\right) \mathrm{ppm} ; \delta_{\mathrm{C}}: 196.1,196.0,163.5$, 149.4, 148.0, 132.6, 121.7, 117.9, 116.2, 115.2, 109.7, 72.7, 45.5, 34.7, 23.4, $22.4 \mathrm{ppm} ; \mathrm{m} / \mathrm{z}: 301[\mathrm{M}+1]^{+}(19), 300[\mathrm{M}]^{+}$(85), $243(18), 226$ (22), 202 (46), 167 (45), 146 (19), 134 (23), 104 (42), 83 (100), 55 (15). Found: C, 67.99; H, $5.37 \%$. Calc. for $\mathrm{C}_{16} \mathrm{H}_{16} \mathrm{O}_{5}$ (300); C, 67.82; $\mathrm{H}, 5.47 \%$.

$4 b, 9 b$-Dihydroxy-2,2-dimethyl-4b,9b-dihydro- $4 H, 5 H$-indeno $\left[2^{\prime}, 1^{\prime}: 4,5\right]$ furo[2,3-d][1,3]dioxine-4,5-dione (3e): This compound was obtained from Meldrum's acid, time reaction $26 \mathrm{~min}$, white powder, yield $87 \%$; m.p. $110-113^{\circ} \mathrm{C}$; FT-IR $v_{\max }$ : 3434, 3254, 2974 , 1727, 1605, 1463, 1389, 1342, 1223, 1097, 976, 764, $654 \mathrm{~cm}^{-1}$; $\delta_{\mathrm{H}}: 7.28-7.15(4 \mathrm{H}, \mathrm{m}, \mathrm{Ar}), 5.33(2 \mathrm{H}, \mathrm{bs}, 2 \times \mathrm{OH}), 1.44(6 \mathrm{H}, \mathrm{s}$, $\left.2 \times \mathrm{CH}_{3}\right) \mathrm{ppm} ; \delta_{\mathrm{C}}: 202.2,192.7,167.4,162.3,144.5,140.5,134.3$, $131.7,129.4,122.0,113.7,86.0,80.1,24.6 \mathrm{ppm} ; \mathrm{m} / z: 304[\mathrm{M}]^{+}(4)$, 290 (15), 202 (10), 167 (25), 149 (68), 125 (19), 114 (100), 97 (39), 86 (40), 71 (51), 57 (67). Found: C, 59.22; H, $3.98 \%$. Calc. for $\mathrm{C}_{15} \mathrm{H}_{12} \mathrm{O}_{7}$ (304); C, 59.40; H, $3.76 \%$.
$4 b, 9 b$-Dihydroxy- $4 b, 9 b$-dihydro- $2 H$-indeno $\left[2^{\prime}, 1^{\prime}: 4,5\right]$ furo [2,3-d] pyrimidine-2,4,5(1H,3H)-trione $(3 \mathrm{f})$ : This compound was obtained from barbituric acid, time reaction $30 \mathrm{~min}$, yellow solid, yield $91 \%$; m.p. $165-167^{\circ} \mathrm{C}$; FT-IR $v_{\text {max }}$ : 3607, 3456, 3175, 2970, 1697, 1583, 1471, 1370, 1247, 1182, 1045, 1009, 970, 852, 772, $730,639,580,525,424 \mathrm{~cm}^{-1} ; \delta_{\mathrm{H}}: 9.43(2 \mathrm{H}, \mathrm{bs}, 2 \times \mathrm{NH}), 7.91-7.85$ $(4 \mathrm{H}, \mathrm{m}, \mathrm{Ar}), 3.37(2 \mathrm{H}, \mathrm{bs}, 2 \times \mathrm{OH}) \mathrm{ppm} ; \delta_{\mathrm{C}}: 204.9,203.0,202.9$, 165.6, 152.2, 137.0, 134.7, 132.6, 124.3, 122.0, 119.3, 87.3, 79.6 ppm; $\mathrm{m} / \mathrm{z}: 288[\mathrm{M}]^{+}$(13), $271(4), 229(17), 211(4), 186(4), 143(20), 128$ (14), 114 (100), 104 (45), 86 (38), 76 (38), 50 (8). Found: C, 54.18; $\mathrm{H}, 2.80 ; \mathrm{N}, 9.72 \%$. Calc. for $\mathrm{C}_{13} \mathrm{H}_{8} \mathrm{~N}_{2} \mathrm{O}_{6}(288) ; \mathrm{C}, 54.00 ; \mathrm{H}, 2.92$; $\mathrm{N}, 9.61 \%$.

$4 b, 9 b$-Dihydroxy-2-thioxo-2,3,4b,9b-tetrahydro- $4 H$-indeno $\left[2^{\prime}, 1^{\prime}: 4,5\right]$ furo[2,3-d]pyrimidine-4,5(1H)-dione $(\mathbf{3 g})$ : This compound was obtained from thiobarbituric acid, time reaction 30 min, white needle, yield $92 \%$; m.p. $190-192{ }^{\circ}$ C; FT-IR $v_{\max }$ : $3585,3515,3070,2969,2879,1712,1590,1528,1433,1378,1289$, $1248,1194,1014,971,889,848,771,724,626,533 \mathrm{~cm}^{-1} ; \delta_{\mathrm{H}}: 10.89$ $(2 \mathrm{H}, \mathrm{s}, 2 \times \mathrm{NH}), 7.92-7.87(4 \mathrm{H}, \mathrm{m}, \mathrm{Ar}), 3.65(2 \mathrm{H}, \mathrm{bs}, 2 \times \mathrm{OH}) \mathrm{ppm}$; 
$\delta_{\mathrm{C}}: 202.1,174.5,163.8,147.3,137.3,135.0,129.0,126.9,124.4,122.1$ $116.4,97.1,85.4 \mathrm{ppm} ; \mathrm{m} / \mathrm{z}: 304[\mathrm{M}]^{+}(5), 290$ (6), $186(3), 160$ (3), 144 (34), 132 (28), 114 (100), 104 (78), 86 (35), 72 (33), 76 (75), 59 (8). Found: C, 51.32; $\mathrm{H}, 2.65 ; \mathrm{N}, 9.21 \%$, Calc. for $\mathrm{C}_{13} \mathrm{H}_{8} \mathrm{~N}_{2} \mathrm{O}_{5} \mathrm{~S}$ (304); C, $51.43 \%, \mathrm{H}, 2.52, \mathrm{~N}, 9.35 \%$.

$4 b, 9 b$-Dihydroxy-1,3-dimethyl-4b,9b-dihydro- $2 H$-indeno[ $\left[2^{\prime}, 1^{\prime}\right.$ : 4,5]furo[2,3- $d$ ]pyrimidine-2,4,5(1H,3H)-trione $(3 \mathrm{~h})$ : This compound was obtained from 1,3-dimethylbarbituric acid, time reaction 30 min, yellow solid, yield $89 \%$; m.p. $128-130{ }^{\circ} \mathrm{C}$; FT-IR $v_{\max }: 3366,2959,2859,1669,1455,1382,1263,1157,1102,990,924$, $884,747,623,493 \mathrm{~cm}^{-1} ; \delta_{\mathrm{H}}: 8.07-8.05(2 \mathrm{H}, \mathrm{m}, \mathrm{Ar}), 7.93-7.90(2 \mathrm{H}, \mathrm{m}$, Ar), $4.99(1 \mathrm{H}, \mathrm{s}, \mathrm{OH}), 4.43(1 \mathrm{H}, \mathrm{s}, \mathrm{OH}), 3.30\left(6 \mathrm{H}, \mathrm{s}, 2 \times \mathrm{CH}_{3}\right) \mathrm{ppm}$; $\delta_{\mathrm{C}}: 198.5,197.4,197.3,150.2,138.0,135.7,132.1,131.6,124.6,122.3$, 111.6, 94.1, 83.2, 26.5, 25.2 ppm; $m / z: 316[\mathrm{M}]^{+}$(5), 300 (5), 186 (6), 156 (41), 132 (38), 104 (100), 76 (91), 50 (8). Found: C, 56.97; H, 3.82; $\mathrm{N}, 8.86 \%$. Calc. for $\mathrm{C}_{15} \mathrm{H}_{12} \mathrm{~N}_{2} \mathrm{O}_{6}(316) ; \mathrm{C}, 56.88 ; \mathrm{H}, 3.96 ; \mathrm{N}, 8.71 \%$.

$4 b, 10 b$-Dihydroxy- $4 b, 10 b$-dihydrodiindeno[1,2-b:2', $\left.1^{\prime}-d\right]$ furan10,11-dione (3i): This compound was obtained from indane1,3-dione, time reaction $27 \mathrm{~min}$, white powder, yield $88 \%$; m.p. 179-181 ${ }^{\circ}$ C; FT-IR $v_{\max }: 3418,3081,2906,1707,1587,1464,1344$, $1265,1155,1083,940,887,797,755,603,443 \mathrm{~cm}^{-1} ; \delta_{\mathrm{H}}: 7.95(4 \mathrm{H}, \mathrm{m}$, Ar), 7.70-7.51 (4H, m, Ar), $4.99(2 \mathrm{H}, \mathrm{bs}, 2 \times \mathrm{OH})$ ppm; $\delta_{\mathrm{C}}: 199.8$, $197.2,169.2,167.8,147.4,141.2,140.5,138.6,128.4,128.1,122.0$, $120.8,113.7,113.0,107.0,105.5,90.0,72.6 \mathrm{ppm} ; \mathrm{m} / \mathrm{z}: 306[\mathrm{M}]^{+}(3)$, 305 (8), 290 (30), 276 (16), 263 (15), 233 (16), 205 (10), 189 (18), 176 (25), 145 (14), 104 (100), 90 (9), 76 (58). Found: C, 70.59; H, $3.29 \%$. Calc. for $\mathrm{C}_{18} \mathrm{H}_{10} \mathrm{O}_{5}$ (306); C, 70.81; $\mathrm{H}, 3.39 \%$.

\section{Results and Discussion}

The synthesis of the heterocyclic compounds started with arylglyoxals as core and used TPAB as an efficient organocatalyst with acceptable results. ${ }^{8}$ As part of the project to develop catalytic applications of TPAB in synthesis of various heterocyclic compounds, it was found that the reaction of ninhydrin (1) with cyclic 1,3-dicarbonyl compounds $\mathbf{2 a - i}$ using TPAB (20 mol\%) in dichloromethane under reflux conditions, afforded indeno $[1,2-b]$ benzofuran derivatives $\mathbf{3 a}-\mathbf{i}$ in excellent yield (Scheme 1 ).

In a preliminary study, the reaction was conducted without any catalyst, as a result, no product was obtained even after $24 \mathrm{~h}$ under reflux conditions (Table 1 , entry 1 ). To determine the optimized reaction conditions for the synthesis of indeno $[1,2-b]$ benzofurans, the reaction of ninhydrin $(1,1 \mathrm{mmol})$ with dimedone $(2 \mathrm{c}, 1 \mathrm{mmol})$ was chosen as a model reaction to produce compound $3 c$, and its behaviour was examined in the presence of several potential catalysts such as TPAB for phase transfer, $p$-TSA as acid source, L-cysteine and L-proline as zwiterions and sodium alginate as a salt, with different molar ratios and various solvents at room temperature ranging to reflux. To find out the appropriate solvent, for the reaction, model reaction was repeated in various solvents such as $\mathrm{H}_{2} \mathrm{O}$, acetone, $\mathrm{CH}_{2} \mathrm{Cl}_{2}$ and $\mathrm{EtOH}$. Reaction in water or dichloromethane in the absence of any catalyst at room temperature or under reflux condition gave no product (Table 1, entry 1). After evaluating a number of different conditions (see Table), the optimum yield (98\%) was obtained when TPAB was used as catalyst, $\mathrm{CH}_{2} \mathrm{Cl}_{2}$ as solvent, 25 min of reaction time and under reflux conditions (Table 1 , entry 21). To peruse the amount of catalyst in our trial reaction, the procedure was optimized using different molar concentrations of TPAB. To this end, an excellent yield of adduct $3 \mathrm{c}$ was obtained using $20 \mathrm{~mol} \%$. On the contrary, lower quantities of the catalyst gave moderate yields of the product at longer reaction times (results not shown). Furthermore, using larger amounts of TPAB was not effective in terms of yields and resulted in large amounts of the starting materials

Table 1 Model reaction for the synthesis of compound $3 c^{\mathrm{a}}$.
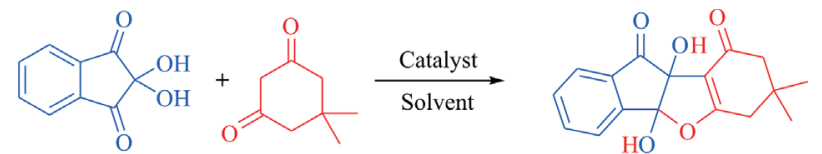

1

$2 c$

$3 \mathbf{c}$

\begin{tabular}{|c|c|c|c|c|c|}
\hline Entry & Solvent & Catalyst (20 mol\%) & Temperature $/{ }^{\circ} \mathrm{C}$ & Time/min & Yield $/ \%$ \\
\hline 1 & $\mathrm{H}_{2} \mathrm{O}$ or $\mathrm{CH}_{2} \mathrm{Cl}_{2}$ & No catalyst & RT-Reflux & $24 \mathrm{~h}$ & - \\
\hline 2 & $\mathrm{H}_{2} \mathrm{O}$ & $p$-TSA & RT -Reflux & $24 \mathrm{~h}$ & - \\
\hline 3 & $\mathrm{H}_{2}^{2} \mathrm{O}$ & Alginate sodium & RT -Reflux & $24 \mathrm{~h}$ & - \\
\hline 4 & $\mathrm{H}_{2}^{2} \mathrm{O}$ & $L$-cysteine & RT -Reflux & $24 \mathrm{~h}$ & - \\
\hline 5 & $\mathrm{H}_{2}^{2} \mathrm{O}$ & $L$-proline & RT -Reflux & $24 \mathrm{~h}$ & - \\
\hline 6 & $\mathrm{H}_{2}^{2} \mathrm{O}$ & ТРAB & RT -Reflux & $24 \mathrm{~h}$ & - \\
\hline 8 & $\mathrm{EtOH}$ & Alginate sodium & RT-Reflux & $24 \mathrm{~h}$ & - \\
\hline 9 & $\mathrm{EtOH}$ & $L$-cysteine & RT-Reflux & $24 \mathrm{~h}$ & - \\
\hline 10 & $\mathrm{EtOH}$ & $L$-proline & RT-Reflux & $24 \mathrm{~h}$ & - \\
\hline 11 & EtOH & ТРAB & RT-Reflux & $24 \mathrm{~h}$ & Trace \\
\hline 12 & Acetone & $p$-TSA & RT-Reflux & $24 \mathrm{~h}$ & - \\
\hline 13 & Acetone & Alginate sodium & RT-Reflux & $24 \mathrm{~h}$ & - \\
\hline 14 & Acetone & L-cysteine & RT-Reflux & $24 \mathrm{~h}$ & - \\
\hline 15 & Acetone & $L$-proline & RT-Reflux & $24 \mathrm{~h}$ & - \\
\hline 17 & $\mathrm{CH}_{2} \mathrm{Cl}_{2}$ & $p$-TSA & RT-Reflux & $24 \mathrm{~h}$ & - \\
\hline 18 & $\mathrm{CH}_{2} \mathrm{Cl}_{2}$ & Alginate sodium & RT-Reflux & $24 \mathrm{~h}$ & - \\
\hline 19 & $\mathrm{CH}_{2} \mathrm{Cl}_{2}$ & $L$-cysteine & RT-Reflux & $24 \mathrm{~h}$ & - \\
\hline 20 & $\mathrm{CH}_{2} \mathrm{Cl}_{2}$ & $L$-proline & RT-Reflux & $24 \mathrm{~h}$ & - \\
\hline 21 & $\mathrm{CH}_{2} \mathrm{Cl}_{2}$ & ТРAB & Reflux & 25 & 98 \\
\hline
\end{tabular}

a The reaction conditions: ninhydrin $(1 \mathrm{mmol})$, dimedone $(1 \mathrm{mmol})$, catalyst $(20 \mathrm{~mol} \%)$, solvent $(2 \mathrm{~mL})$, temperature reflux.

${ }^{b}$ Isolated yield. The bold type (entry 21 ) refers to the best reaction conditions.

'-' indicates no reaction. 
remaining unconverted. The respective results of the investigations are displayed in Table 1.

Based on our survey and optimization of the reaction conditions, the generality and the scope of the organocatalyst in the synthesis process of $\mathbf{3 a - i}$ were assessed by reaction of ninhydrin (1) with different cyclic 1,3-dicarbonyl compounds 2a-i (Scheme 1 ). As depicted in Scheme 1, the desired compounds were obtained in excellent yields and short reaction times from all of the reactions. Formation of the indeno[1,2-b]benzofurans system were confirmed by studying FT-IR, ${ }^{1} \mathrm{H}-\mathrm{NMR},{ }^{13} \mathrm{C}-\mathrm{NMR}$, mass spectral data and microanalysis, beside comparison of the obtained spectral data of known compounds with those reported in the literature.

In terms of spectroscopic characterization, the ${ }^{1} \mathrm{H}$ NMR spectrum of product $\mathbf{3 d}$ showed a characteristic broad singlet at $\delta=$ $5.51 \mathrm{ppm}$ attributable to the $\mathrm{OH}$ groups, which was exchanged by $\mathrm{D}_{2} \mathrm{O}$. Aromatic protons appeared as multiplet at $\delta=\sim 7.65$ $7.90 \mathrm{ppm}$, methylene groups gave broad singlets at $\delta=2.26$ and $1.27 \mathrm{ppm}$, and methyl groups displayed a singlet at $\delta=$ $1.03 \mathrm{ppm}$. The ${ }^{13} \mathrm{C}$ NMR spectrum showed 16 peaks for all the different carbons as expected. Moreover, the FT-IR (KBr) spectrum of $\mathbf{3 d}$, showed the characteristic absorptions bands at 1711 and $1660 \mathrm{~cm}^{-1}$ due to the vibrations of different carbonyl groups, and its mass spectrum showed the molecular ion at $\mathrm{m} / \mathrm{z} 300$ and a peak at $m / z 83$ with $100 \%$ abundance as base peak.

The recyclability of TPAB was also investigated for the synthesis of $3 \mathbf{c}$. In this respect, the catalyst was recovered and reused more than four times for obtaining $4 b, 9 b$-dihydroxy-8,8dimethyl-4b,8,9,9b-tetrahydro- $7 \mathrm{H}$-indeno[1,2- $b]$ benzofuran6,10-dione (3c). No significant loss of catalytic efficiency was observed (Fig. 1).

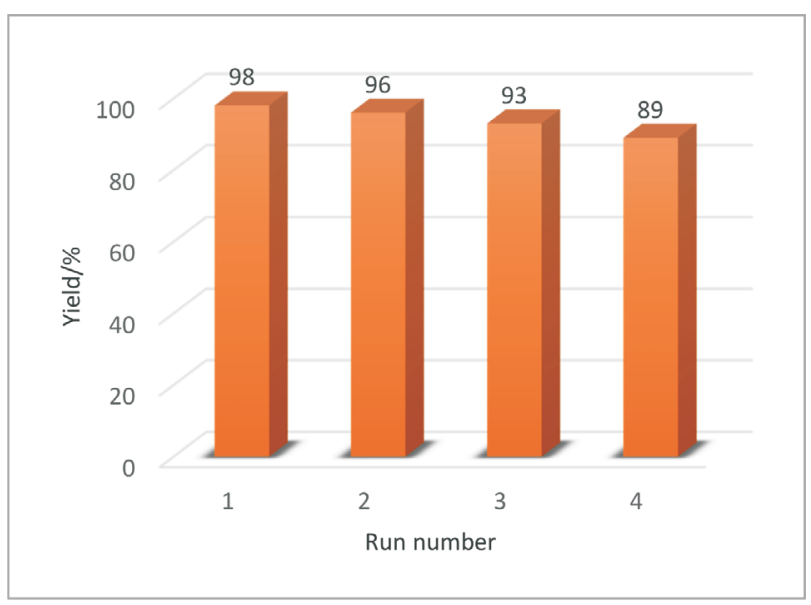

Figure 1 Reusability of TPAB for the synthesis of 3c.

\section{Conclusions}

In conclusion, a highly efficient and easy procedure was reported for the synthesis of a new series of indeno[2,1- $b]$ benzofuran derivatives $3 \mathbf{a}-\mathbf{i}$ in excellent yields, by reaction of ninhydrin and cyclic 1,3-dicarbonyl compounds using $20 \mathrm{~mol} \%$ TPAB as an organocatalyst in $\mathrm{CH}_{2} \mathrm{Cl}_{2}$ as solvent. The reasonable reaction times, simple work-up, high yields and recoverability of the catalyst are the main merits of this procedure. The final obtained products are suitable for the synthesis of a series of polycyclic heterocycles that may show potential antimicrobial and inhibitory properties.

\section{Acknowledgements}

The authors are grateful to Urmia University for its support of this work.

\section{Supplementary Material}

Supplementary information is provided in the online supplement.

\section{${ }^{s}$ ORCID iDs}

$\begin{array}{ll}\text { A. Poursattar Marjani: } & \text { (D) orcid.org/0000-0002-5899-4285 } \\ \text { J. Khalafy: } & \text { (iD) orcid.org/0000-0003-1202-2664 }\end{array}$

\section{References}

1 S.H. Mehdi, R. Hashim, R.M. Ghalib, M.F.C.G. da Silva, O. Sulaiman, S.Z. Rahman, V. Murugaiyah and M.M. Marimuthu, Synthesis, characterization, antimicrobial and enzymatic activity of $4 b, 9 b$-dihydroxy-7,8-dihydro-4bH-indeno[1,2-b] benzofuran-9,10(6H,9bH)dione, J. Mol. Struct., 2001, 1006, 318-323.

2 a) J.M. Kim, K.Y. Lee and J.N. Kim, Oxidative aromatization of 2-acylcyclohexane-1,3-dione derivatives using Iodine in methanol, Bull. Korean Chem. Soc., 2003, 24, 1057-1058. b) J.E. Na, J. M. Kim, S. Lee and J.N. Kim, Synthesis of benzo[b]indeno[2,1- $d]$ furanone skeleton from ninhydrin and cyclohexane-1,3-dione derivatives, Bull. Korean Chem. Soc., 2003, 24, 1725-1726. c) J.E. Na, S. GowriSankar, S. Lee and J.N. Kim, Selective methylation of the ninhydrin-phenol adducts with $\mathrm{I}_{2}$ in MeOH, Bull. Korean Chem. Soc., 2004, 25, 569-572.

3 T. Chanda and M.S. Singh, Developments toward the synthesis and application of 3-hydroxyindanones, Org. Biomol. Chem., 2016, 14, 8895-8910.

4 Y. Saini, R. Khajuria, L.K. Rana, G. Hundal, V.K. Gupta, R. Kant and K.K. Kapoor, Unprecedented reaction of ninhydrin with ethyl cyanoacetate and diethyl malonate on ultrasonic irradiation, Tetrahedron., 2016, 72, 257-263.

5 a) K.R. Prabhakar, V.P. Veerapuri, P. Bansal, K.P. Vipan, K.M. Reddy, A. Barik, B.K.D. Reddy, P. Reddanna, K.I. Priyadarsini and M.K. Unnikrishnan, Identification and evaluation of antioxidant, analgesic/anti-inflammatory activity of the most active ninhydrin phenol adducts synthesized, Bioorg. Med. Chem. 2006, 14, 7113-7120. b) S. Mahendran, S. Badami, S. Ravi, B.S. Thippeswamy and V. P. Veerapur, Antioxidant, analgesic and anti-inflammatory properties of new ninhydrin adduct of embelin, Pharm. Chem. J., 2011, 45, 547-551.

6 a) R.J. Argauer and G.R. Landolt, Acid-free nitration of benzene and toluene in zeolite NaZSM-5, U.S. Patent. 3702886 1972. b) C. Bolm, A.S. Magnus and J.P. Hildebrand, Catalytic synthesis of aldehydes and ketones under mild conditions using TEMPO/Oxone, Org. Lett., 2000, 2, 1173-1175.

7 a) J. Khalafy, M. Ezzati, P. Madadi, A. Poursattar Marjani and H. Yaghoobnejad Asl, Synthesis of some 5-[2-aryl-2-oxoethyl]-1,3dimethylpyrimidine-2,4,6-trione derivatives by a one-pot, threecomponent reaction, S. Afr. J. Chem., 2017, 70, 132-136. b) M. Ezzati, J. Khalafy, A. Poursattar Marjani and R.H. Prager, The catalyst-free syntheses of pyrazolo[3,4- $b]$ quinolin-5-one and pyrazolo $\left[4^{\prime}, 3^{\prime}: 5,6\right]$ pyrido[2,3- $d$ ] pyrimidin-5,7-dione derivatives by one-pot, threecomponent reactions, Tetrahedron, 2017, 73, 6587-6596. c) A. Poursattar Marjani, J. Khalafy, F. Majidi Arlan and E. Eyni, A simple protocol for the green synthesis of a new series of pyrimido[4,5- $b$ ] $[1,6]$ naphthyridines in the presence of silver nanoparticles (AgNPs), ARKIVOC, 2019, v, 1-9.

8 a) M. Ezzati, J. Khalafy, A. Poursattar Marjani and R.H. Prager, An efficient one-pot, four-component synthesis of pyrazolo[3,4-b]pyridines catalyzed by tetrapropylammonium bromide (TPAB) in water, Aust. J. Chem., 2018, 71, 435-441. b) A. Poursattar Marjani, J. Khalafy and A. Farajollahi, Synthesis of ethyl 2-amino-4-benzoyl-5-oxo-5,6dihydro-4H-pyrano[3,2-c]quinoline-3-carboxylates by a one-pot, three-component reaction in the presence of TPAB, J. Heterocycl. Chem., 2019, 56, 268-274. c) A. Poursattar Marjani, J. Khalafy and S. Akbarzadeh, Synthesis of pyrazolopyridine and pyrazoloquinoline derivatives by one-pot, three-component reactions of arylglyoxals, 3-methyl-1-aryl-1H-pyrazol-5-amines and cyclic 1,3-dicarbonyl compounds in the presence of tetrapropylammonium bromide, Green Process Synth., 2019, 8, 533-541. d) N. Etivand, J. Khalafy and A. Poursattar Marjani, Facile, one-pot, four-component synthesis of a new series of imidazo[1,2-a]pyridines in presence of TPAB in $\mathrm{EtOH}$ under reflux conditions, Res. Chem. Intermediat., 2019, 45, 3379-3394. 


\section{Supplementary material to:}

A. Poursattar Marjani, J. Khalafy and S. Akbarzadeh,

Synthesis of Indeno[1,2-b]benzofurans using TPAB as Highly Efficient and Recoverable Catalyst,

S. Afr. J. Chem., 2019, 72, 160-163. 


\title{
Supplementary Information
}

\section{Synthesis of Indeno[1,2- $b]$ benzofurans using TPAB as Highly Efficient and Recoverable Catalyst}

\author{
Ahmad Poursattar Marjani*, Jabbar Khalafy and Somayeh Akbarzadeh \\ Department of Organic Chemistry, Faculty of Chemistry, Urmia University, Urmia, Iran \\ *E-mail: a.poursattar@gmail.com; a.poursattar@urmia.ac.ir
}

\section{Content}

page

Fig. S1. ${ }^{1} \mathrm{H}$ NMR spectrum $\left(300 \mathrm{MHz}\right.$, DMSO- $\left.d_{6}\right)$ of compound 3a

Fig. S2. ${ }^{13} \mathrm{C}$ NMR spectrum $\left(75.5 \mathrm{MHz}\right.$, DMSO- $\left.d_{6}\right)$ of compound 3a

Fig. S3. IR spectrum $(\mathrm{KBr})$ of compound 3a

Fig. S4. Mass spectrum of compound 3a

Fig. S5. ${ }^{1} \mathrm{H}$ NMR spectrum $\left(300 \mathrm{MHz}, \mathrm{CDCl}_{3}\right)$ of compound 3d

3

Fig. S6. ${ }^{13} \mathrm{C}$ NMR spectrum $\left(75.5 \mathrm{MHz}, \mathrm{CDCl}_{3}\right)$ of compound 3d

Fig. S7. IR spectrum ( $\mathrm{KBr})$ of compound 3d

4

Fig. S8. Mass spectrum of compound 3d

Fig. S9. ${ }^{1} \mathrm{H}$ NMR spectrum $\left(300 \mathrm{MHz}, \mathrm{CDCl}_{3}\right)$ of compound 3e

Fig. S10. ${ }^{13} \mathrm{C}$ NMR spectrum $\left(75.5 \mathrm{MHz}, \mathrm{CDCl}_{3}\right)$ of compound 3e

Fig. S11. IR spectrum $(\mathrm{KBr})$ of compound $\mathbf{3 e}$

Fig. S12. Mass spectrum of compound 3e

Fig. S13. ${ }^{1} \mathrm{H}$ NMR spectrum $\left(300 \mathrm{MHz}\right.$, DMSO- $\left.d_{6}\right)$ of compound $\mathbf{3 f}$

Fig. S14. ${ }^{13} \mathrm{C}$ NMR spectrum $\left(75.5 \mathrm{MHz}\right.$, DMSO- $\left.d_{6}\right)$ of compound $\mathbf{3 f}$

Fig. S15. IR spectrum $(\mathrm{KBr})$ of compound $\mathbf{3 f}$

Fig. S16. Mass spectrum of compound $3 \mathbf{f}$

Fig. S17. ${ }^{1} \mathrm{H}$ NMR spectrum $\left(300 \mathrm{MHz}, \mathrm{DMSO}-d_{6}\right)$ of compound $\mathbf{3 g}$

5

Fig. S18. ${ }^{13} \mathrm{C}$ NMR spectrum $\left(75.5 \mathrm{MHz}\right.$, DMSO- $\left.d_{6}\right)$ of compound $\mathbf{3 g}$

Fig. S19. IR spectrum $(\mathrm{KBr})$ of compound $3 \mathrm{~g}$

Fig. S20. Mass spectrum of compound 3g

5

Fig. S21. ${ }^{1} \mathrm{H}$ NMR spectrum $\left(300 \mathrm{MHz}, \mathrm{CDCl}_{3}\right)$ of compound $\mathbf{3 h}$

Fig. S22. ${ }^{13} \mathrm{C}$ NMR spectrum $\left(75.5 \mathrm{MHz}, \mathrm{CDCl}_{3}\right)$ of compound $\mathbf{3 h} \quad \mathbf{1 2}$

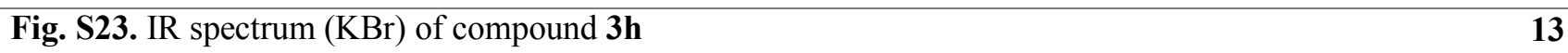

Fig. S24. Mass spectrum of compound 3h $\quad 13$

Fig. S25. ${ }^{1} \mathrm{H}$ NMR spectrum (300 MHz, DMSO- $\left.d_{6}\right)$ of compound 3i $\quad 14$

Fig. S26. ${ }^{13} \mathrm{C}$ NMR spectrum $\left(75.5 \mathrm{MHz}, \mathrm{DMSO}-d_{6}\right)$ of compound 3i $\quad \mathbf{1 4}$

Fig. S27. IR spectrum (KBr) of compound 3i $\quad 15$

Fig. S28. Mass spectrum of compound 3i $\quad 15$ 
Fig. S1. ${ }^{1} \mathrm{H}$ NMR spectrum (300 MHz, DMSO- $d_{6}$ ) of compound 3a.

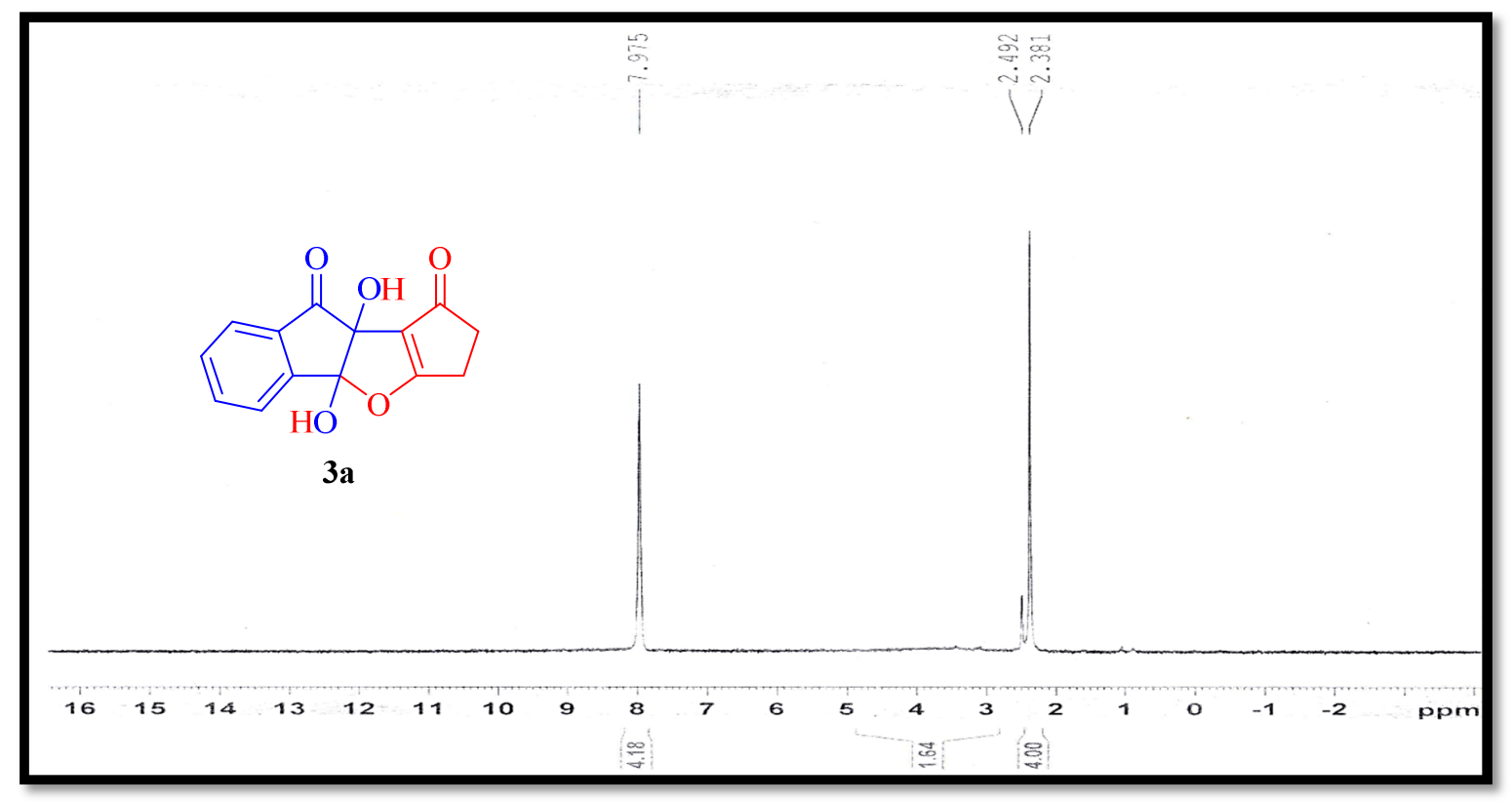

Fig. S2. ${ }^{13} \mathrm{C}$ NMR spectrum (75.5 MHz, DMSO- $d_{6}$ ) of compound 3a.

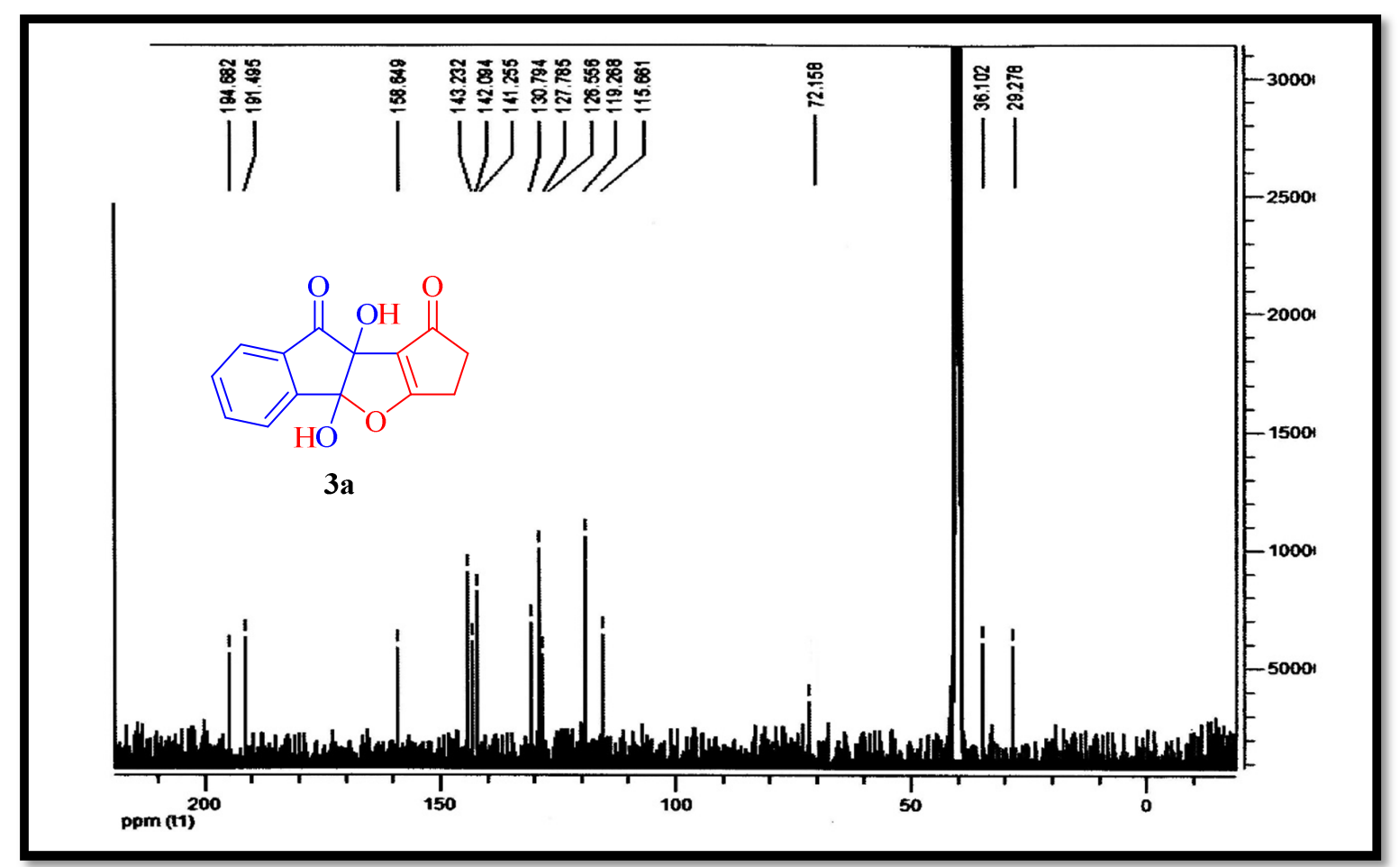


Fig. S3. IR spectrum $(\mathrm{KBr})$ of compound 3a.

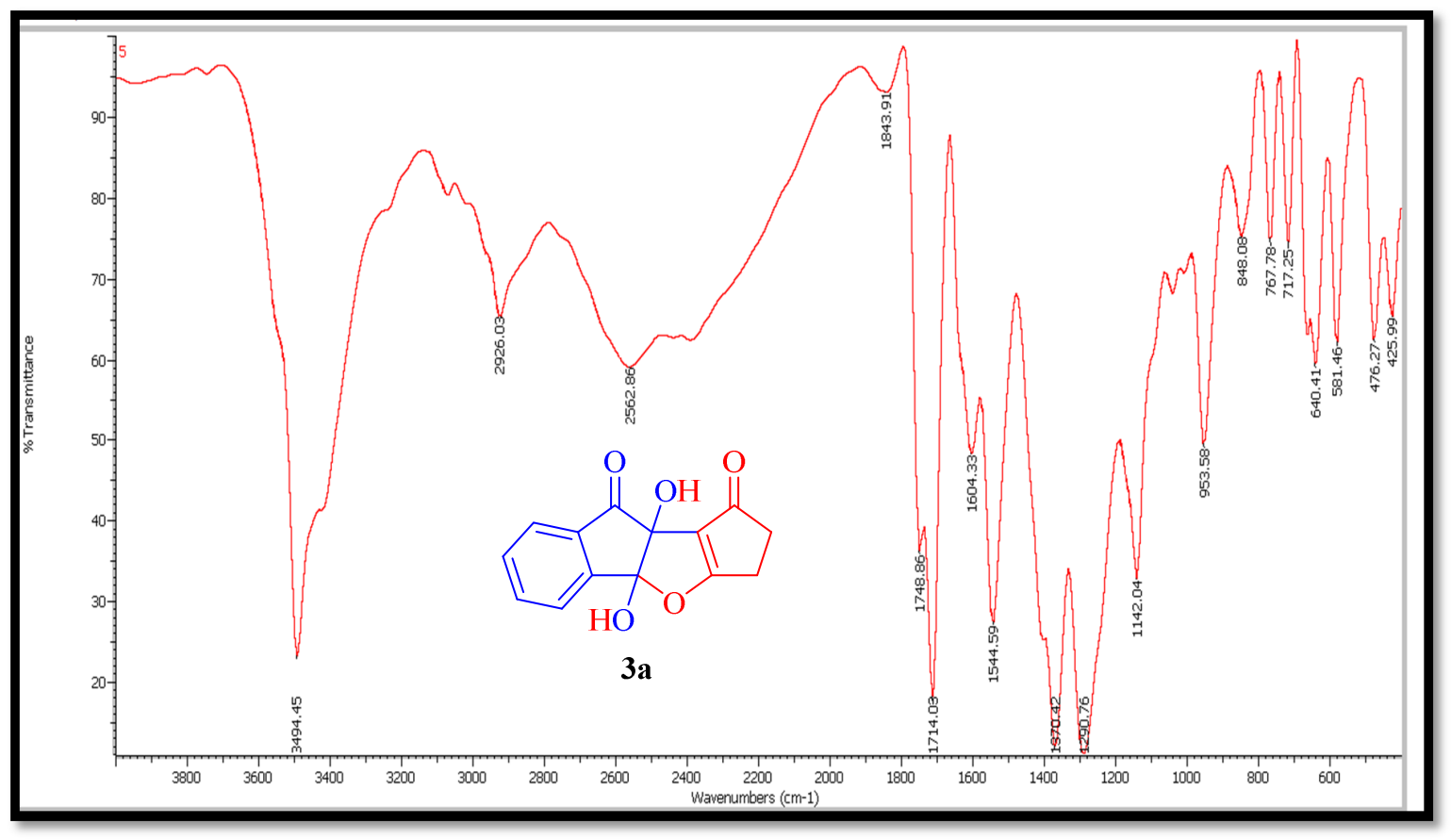

Fig. S4. Mass spectrum of compound 3a.

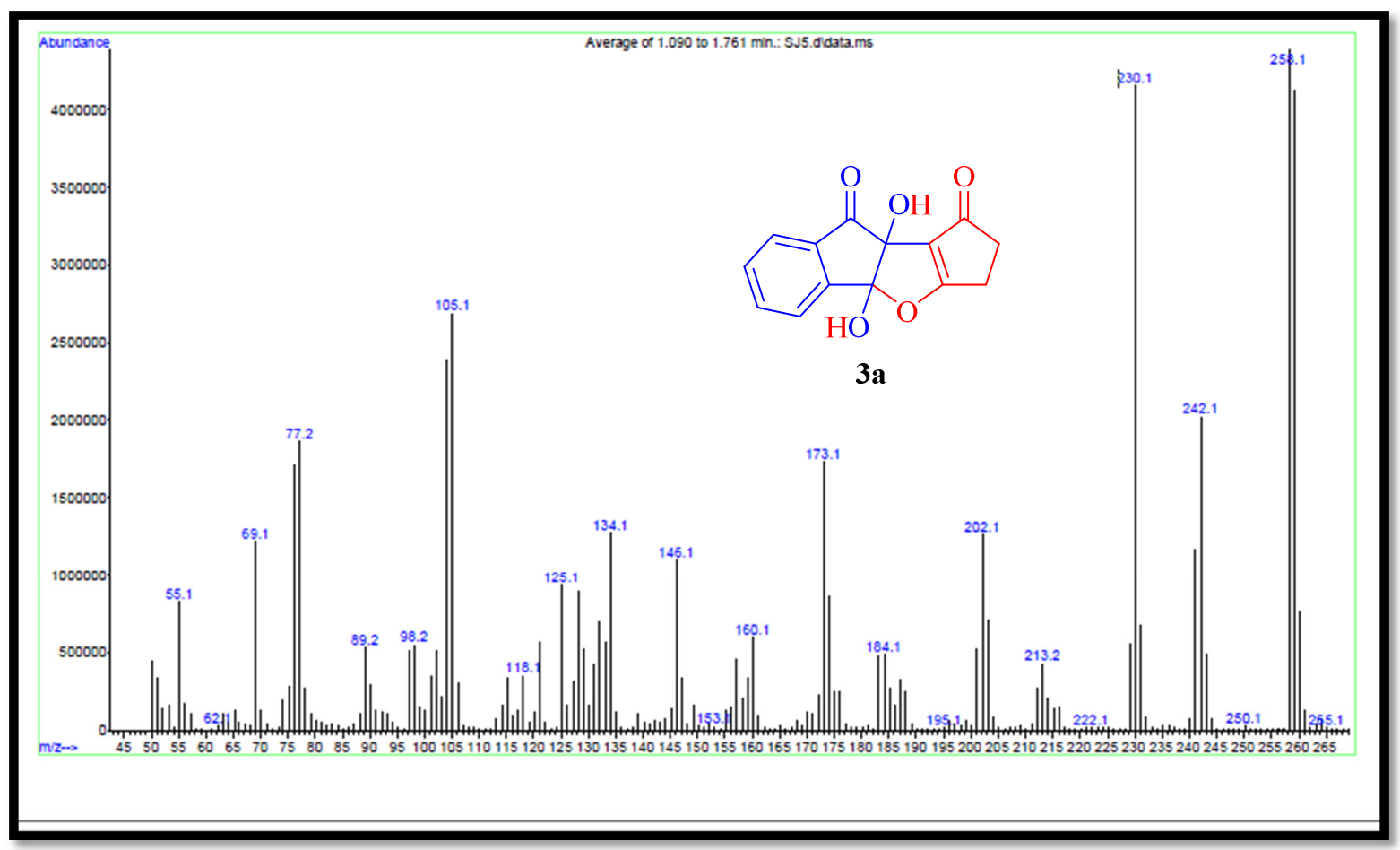


4b,9b-Dihydroxy-6,6-dimethyl-6,7,8,9b-tetrahydro-9H-indeno[1,2-b]benzofuran-9,10(4bH)-dione (3d)

Fig. S5. ${ }^{1} \mathrm{H}$ NMR spectrum $\left(300 \mathrm{MHz}, \mathrm{CDCl}_{3}\right)$ of compound $\mathbf{3 d}$.

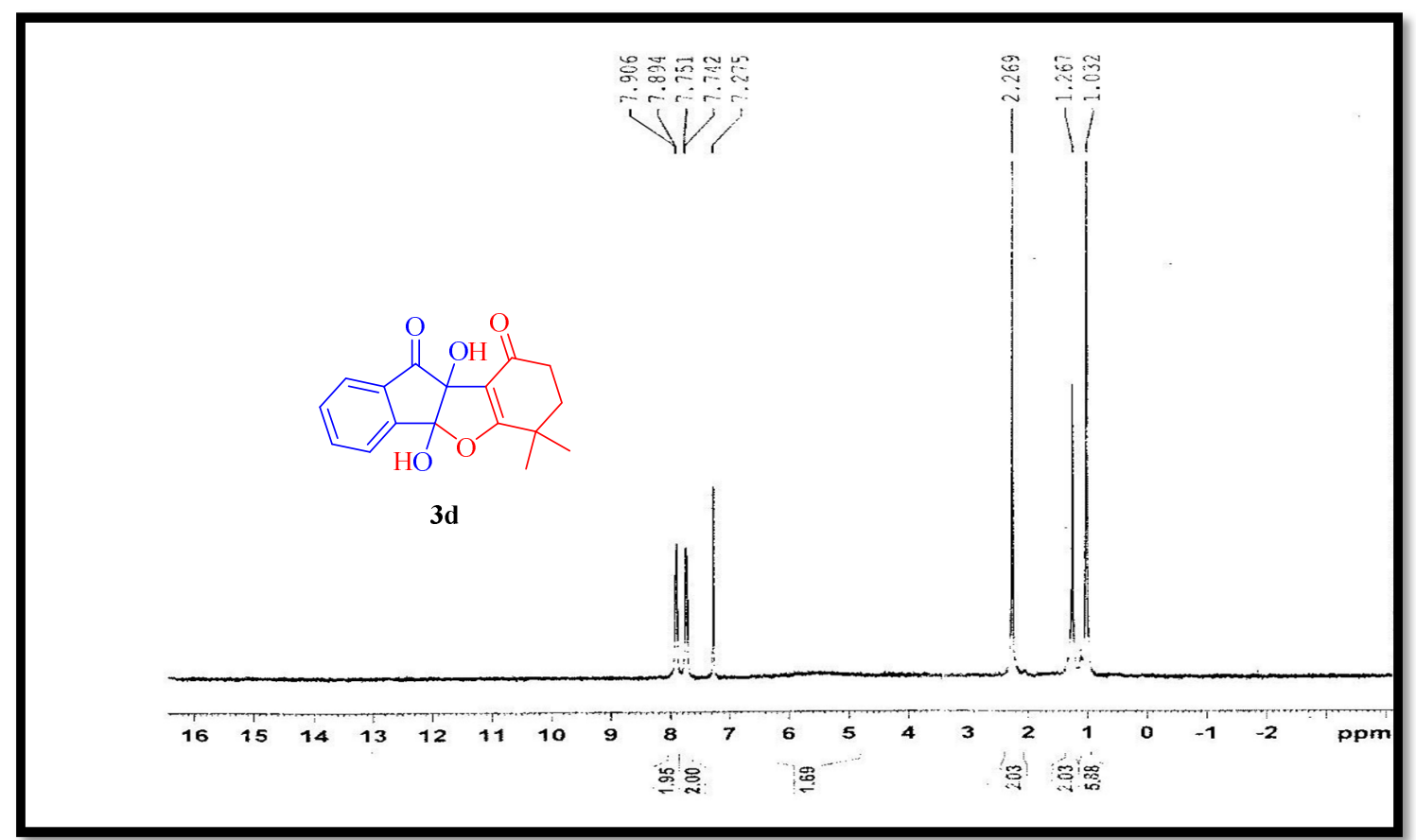

Fig. S6. ${ }^{13} \mathrm{C}$ NMR spectrum $\left(75.5 \mathrm{MHz}, \mathrm{CDCl}_{3}\right)$ of compound 3d.

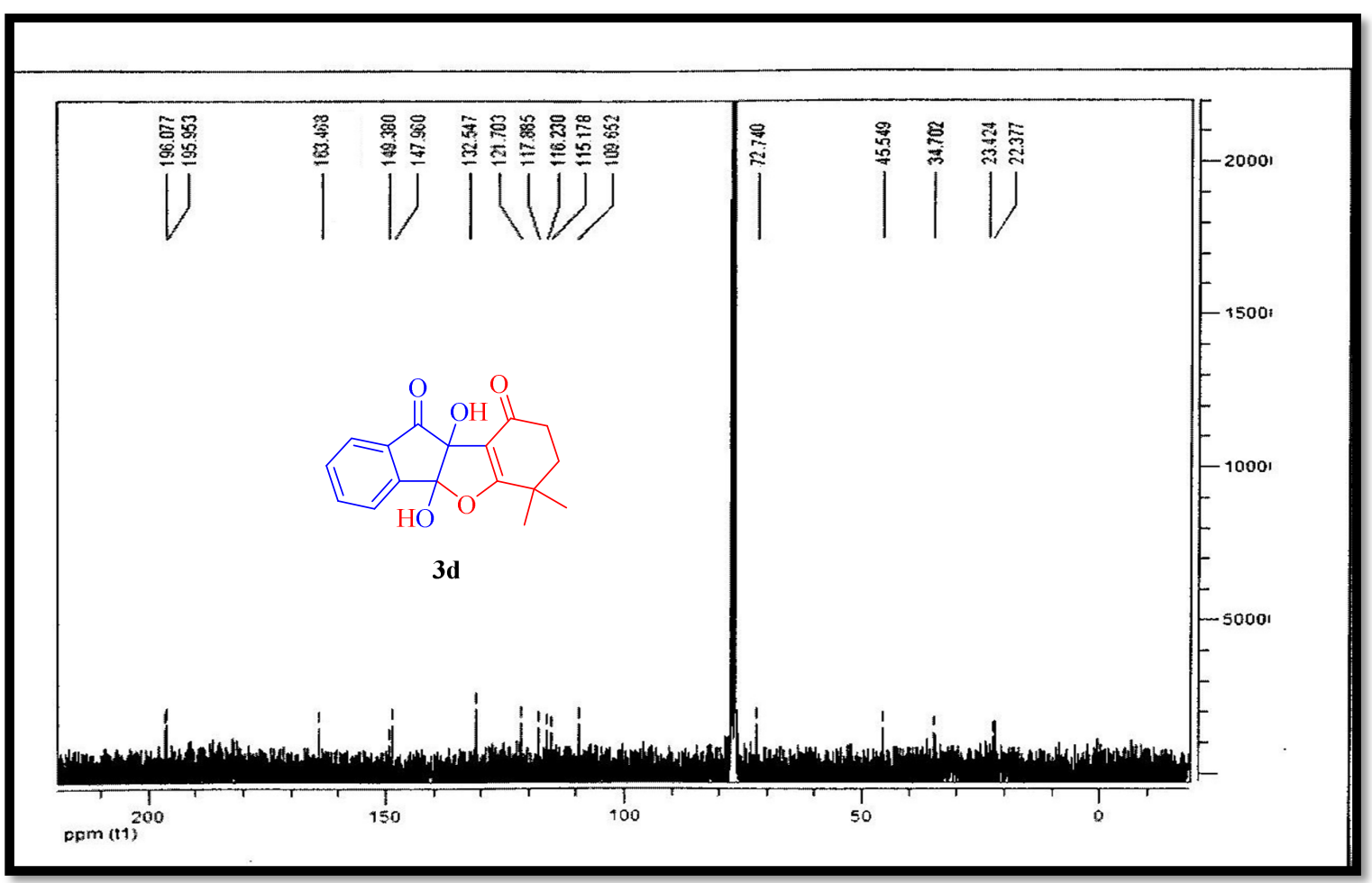


Fig. S7. IR spectrum (KBr) of compound 3d.

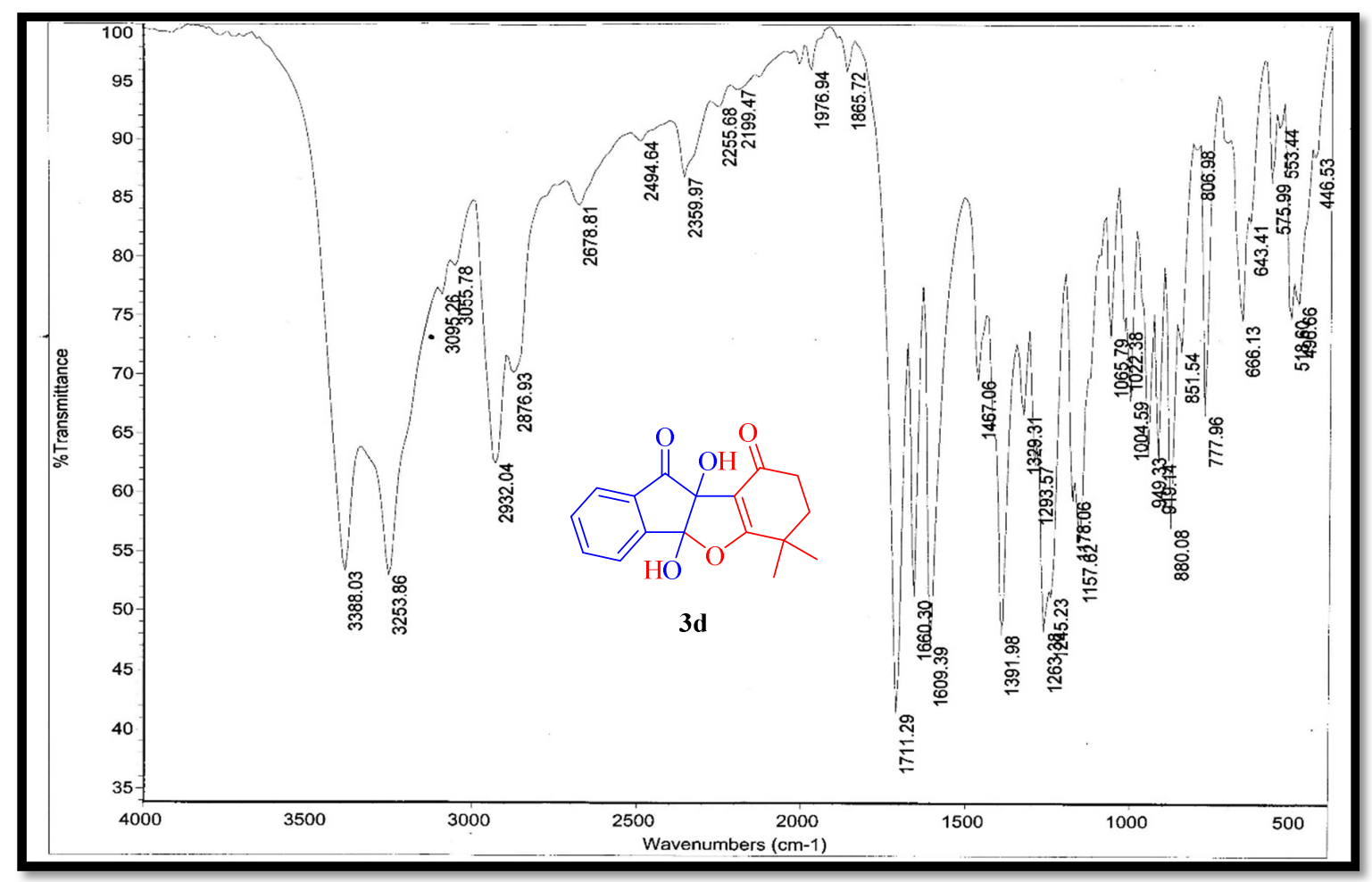

Fig. S8. Mass spectrum of compound 3d.

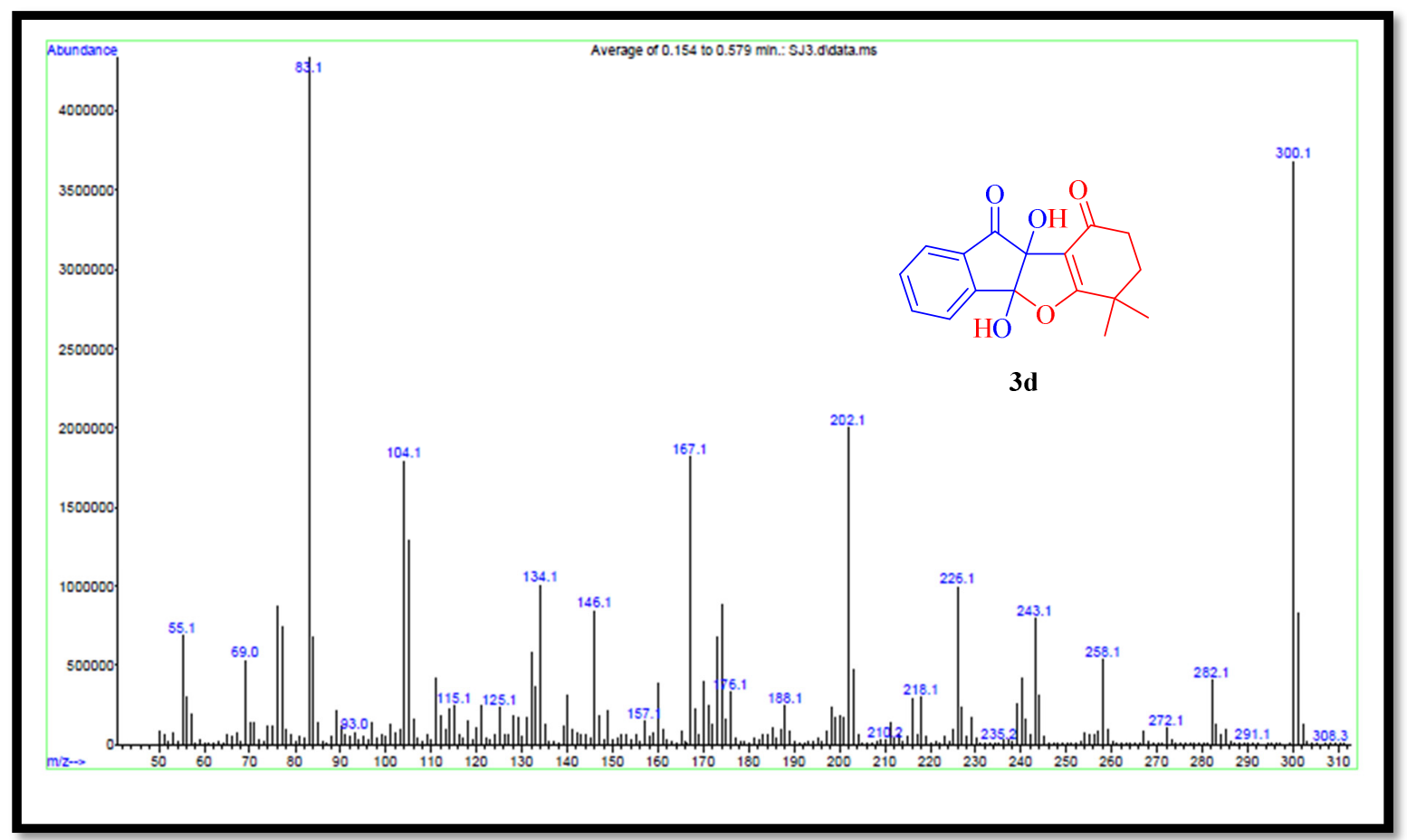


4b,9b-Dihydroxy-2,2-dimethyl-4b,9b-dihydro-4H,5H-indeno[2',1':4,5]furo[2,3d] [1,3] dioxine-4,5-dione (3e)

Fig. S9. ${ }^{1} \mathrm{H}$ NMR spectrum $\left(300 \mathrm{MHz}, \mathrm{CDCl}_{3}\right)$ of compound $3 \mathbf{3 e}$

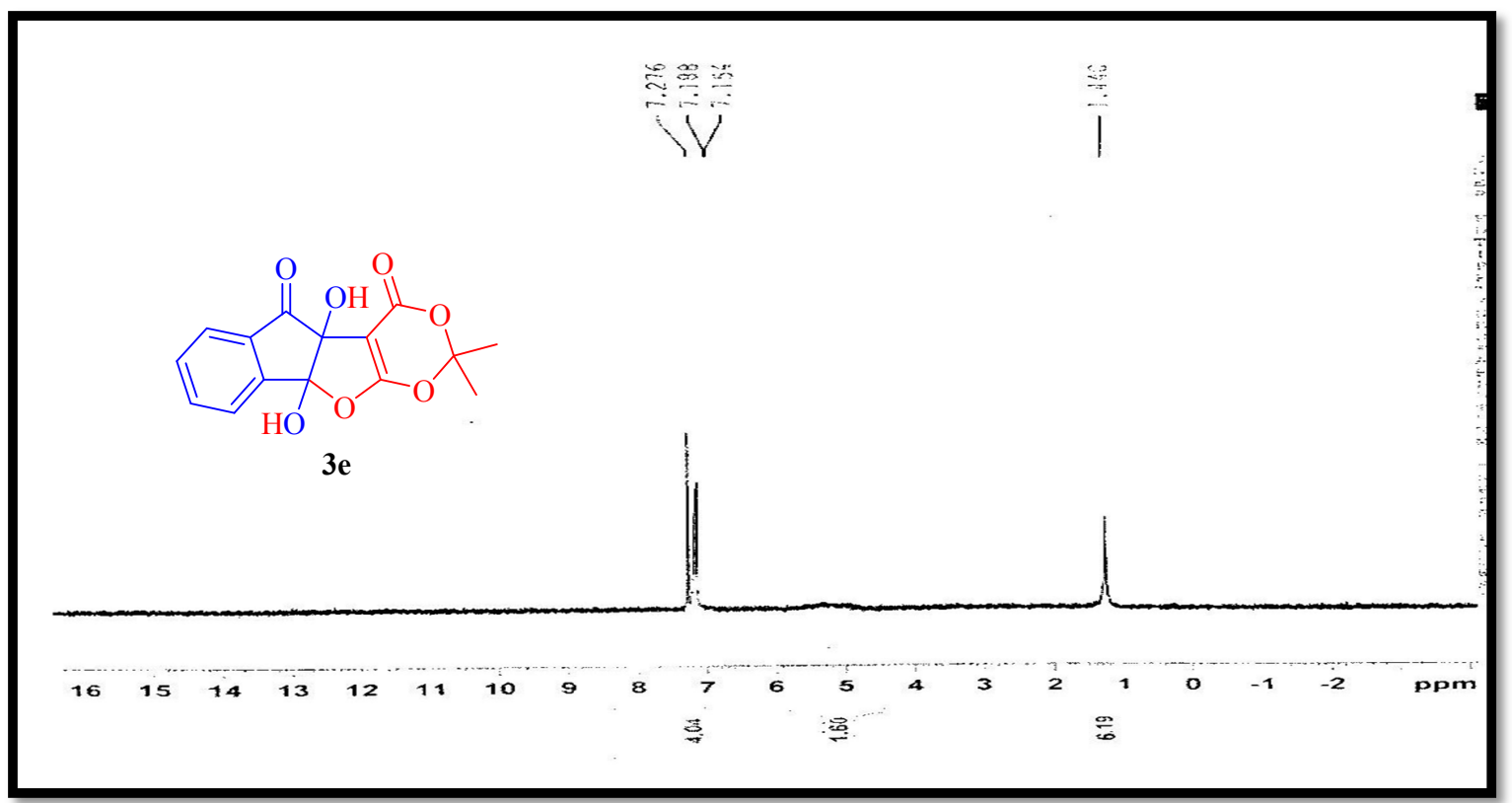

Fig. S10. ${ }^{13} \mathrm{C}$ NMR spectrum $\left(75.5 \mathrm{MHz}, \mathrm{CDCl}_{3}\right)$ of compound 3e.

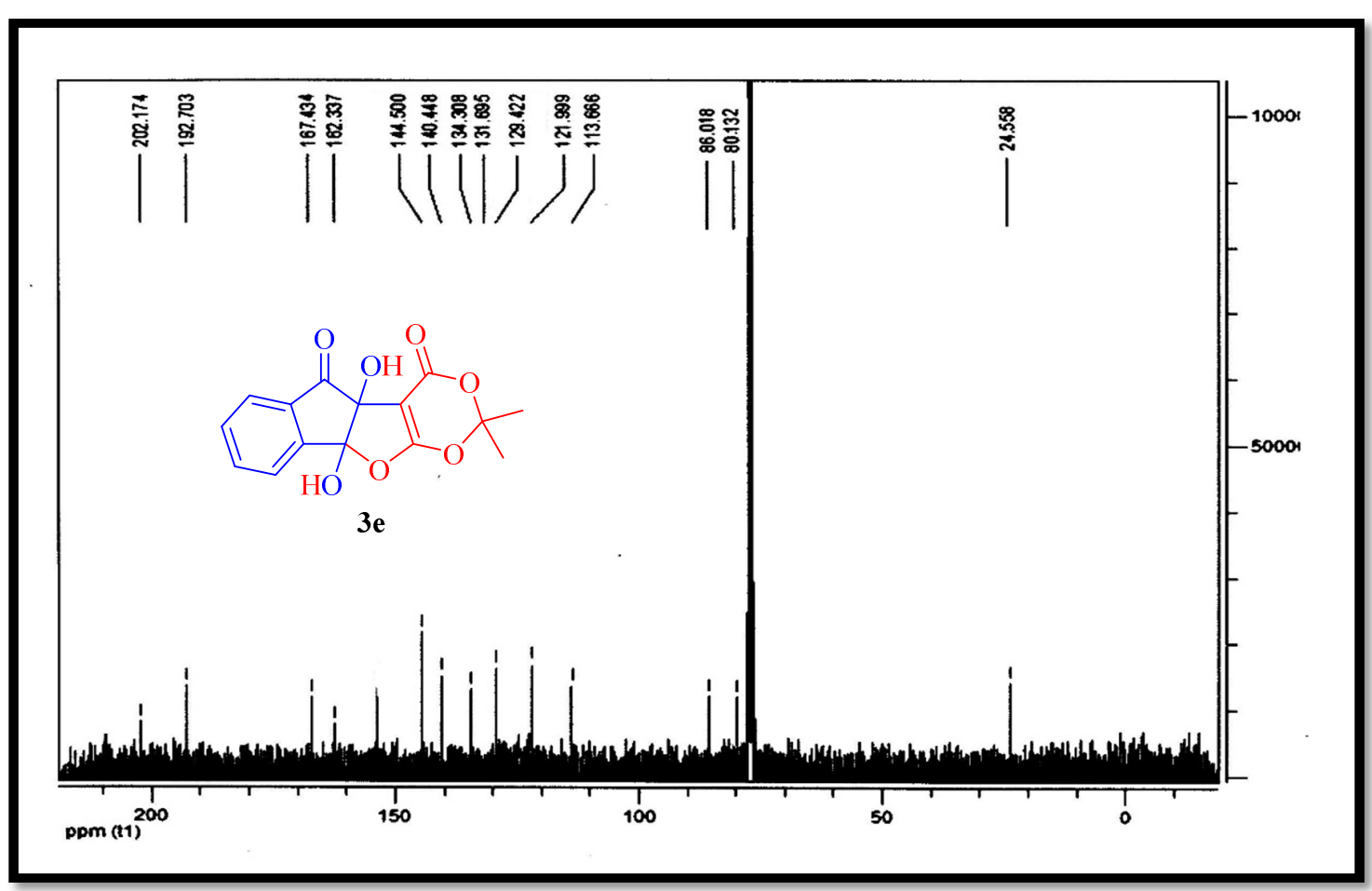


Fig. S11. IR spectrum (KBr) of compound $3 \mathbf{e}$.

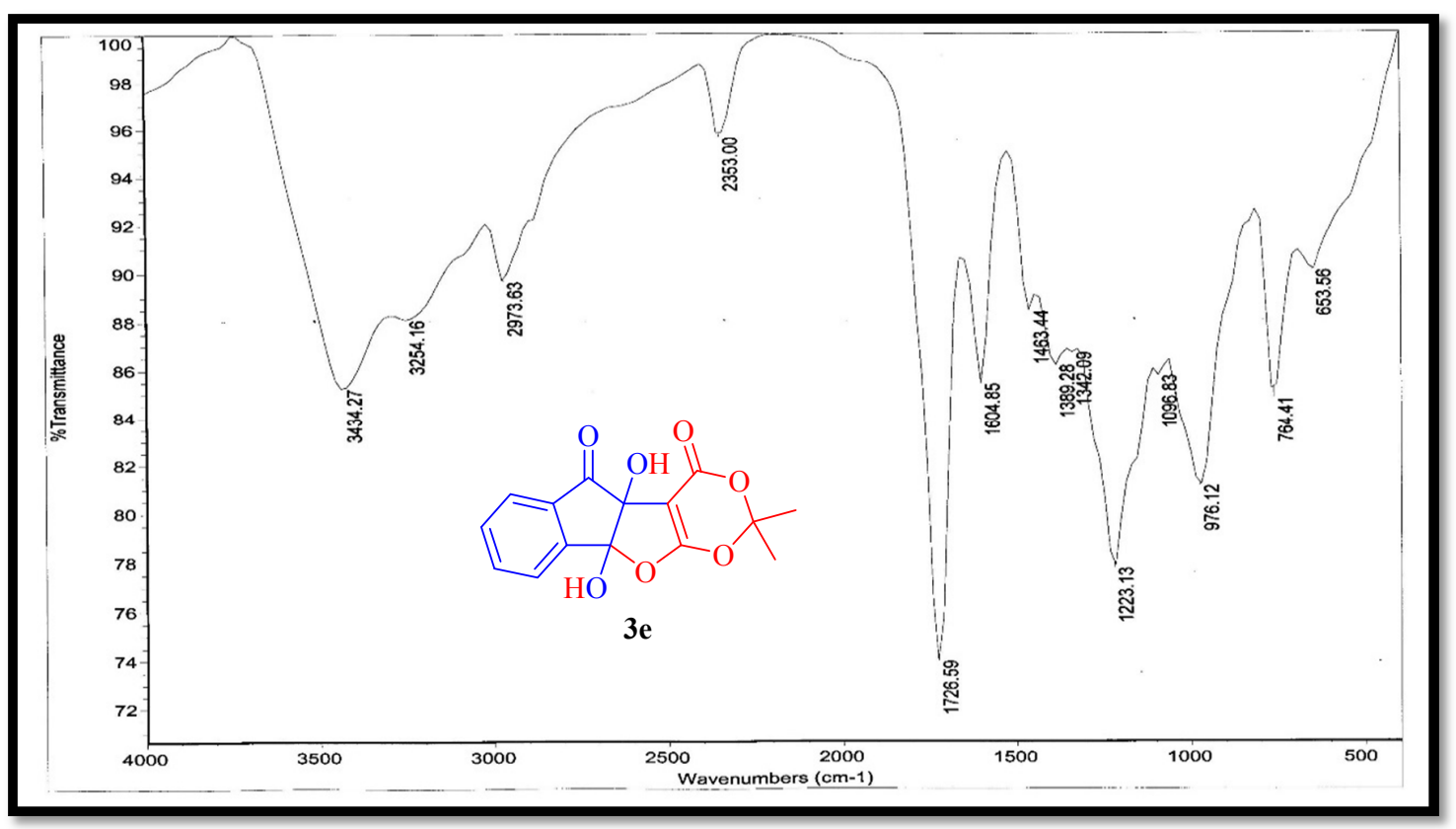

Fig. S12. Mass spectrum of compound 3e.

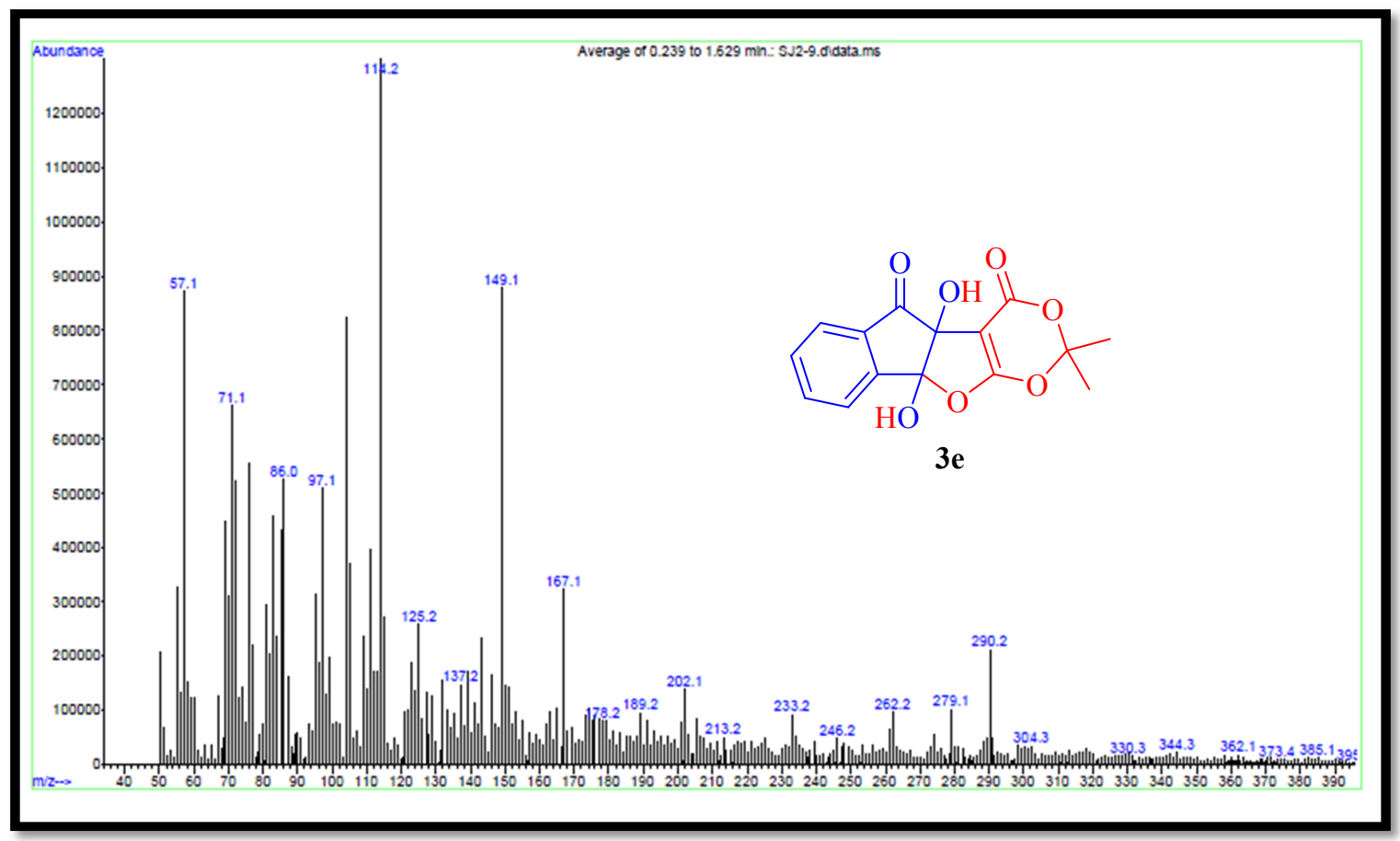


4b,9b-Dihydroxy-4b,9b-dihydro-2H-indeno $\left[2^{\prime}, 1^{\prime}: 4,5\right]$ furo $[2,3-d]$ pyrimidine-2,4,5(1H,3H)trione (3f):

Fig. S13. ${ }^{1} \mathrm{H}$ NMR spectrum (300 MHz, DMSO- $\left.d_{6}\right)$ of compound $3 \mathbf{3}$.

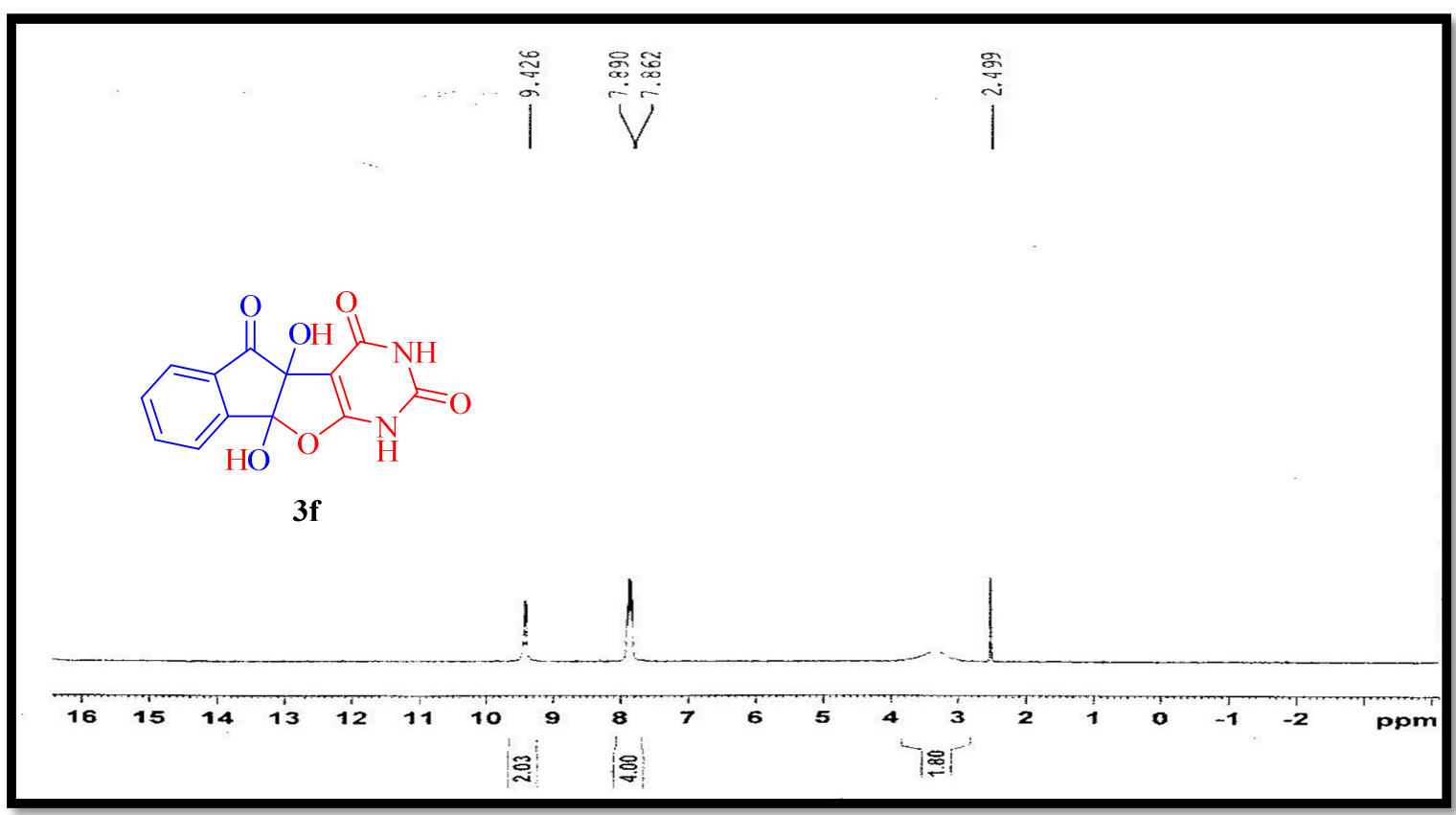

Fig. S14. ${ }^{13} \mathrm{C}$ NMR spectrum $\left(75.5 \mathrm{MHz}, \mathrm{DMSO}-d_{6}\right)$ of compound $3 \mathbf{3 f}$.

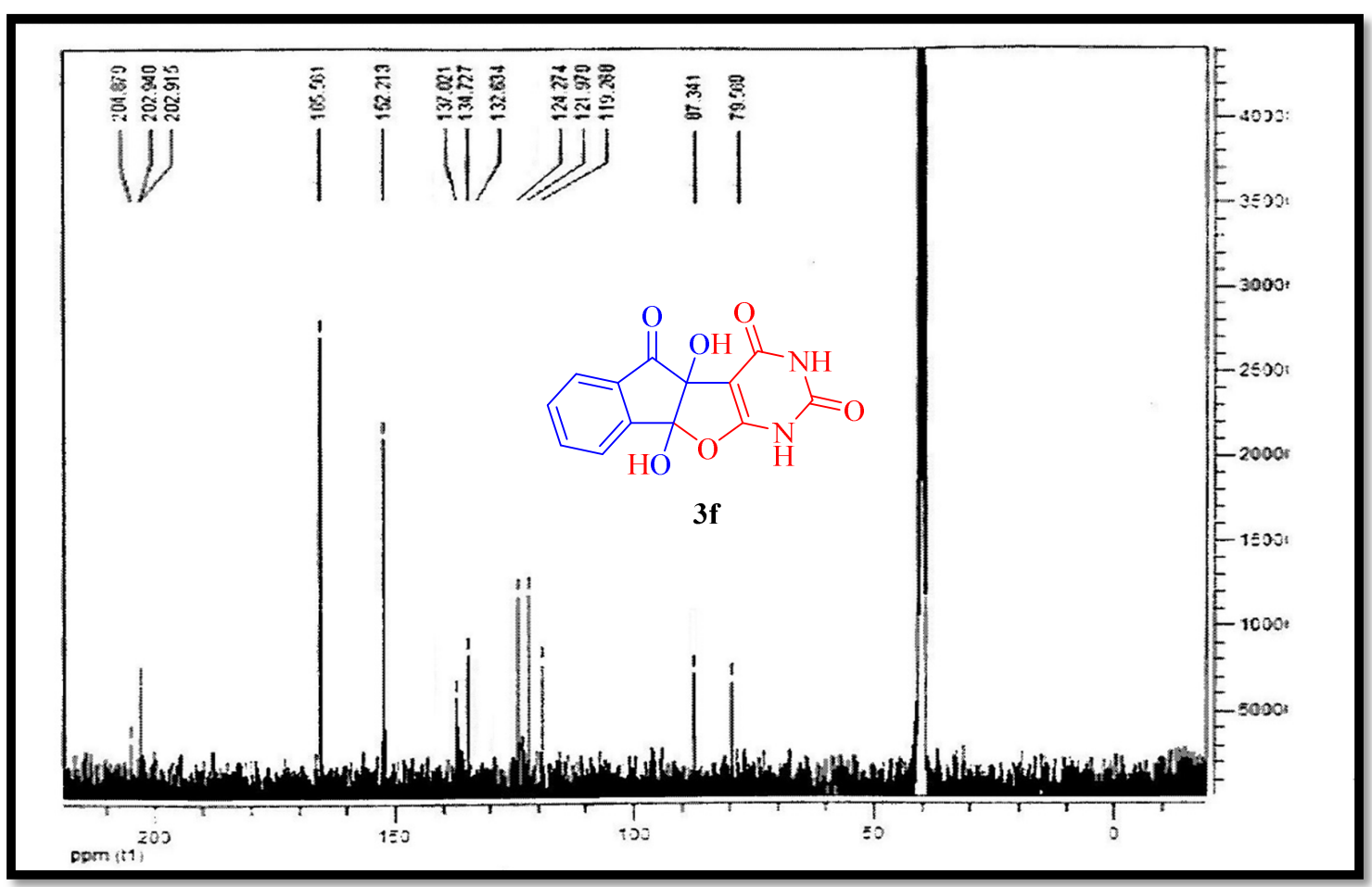


Fig. S15. IR spectrum (KBr) of compound 3f.

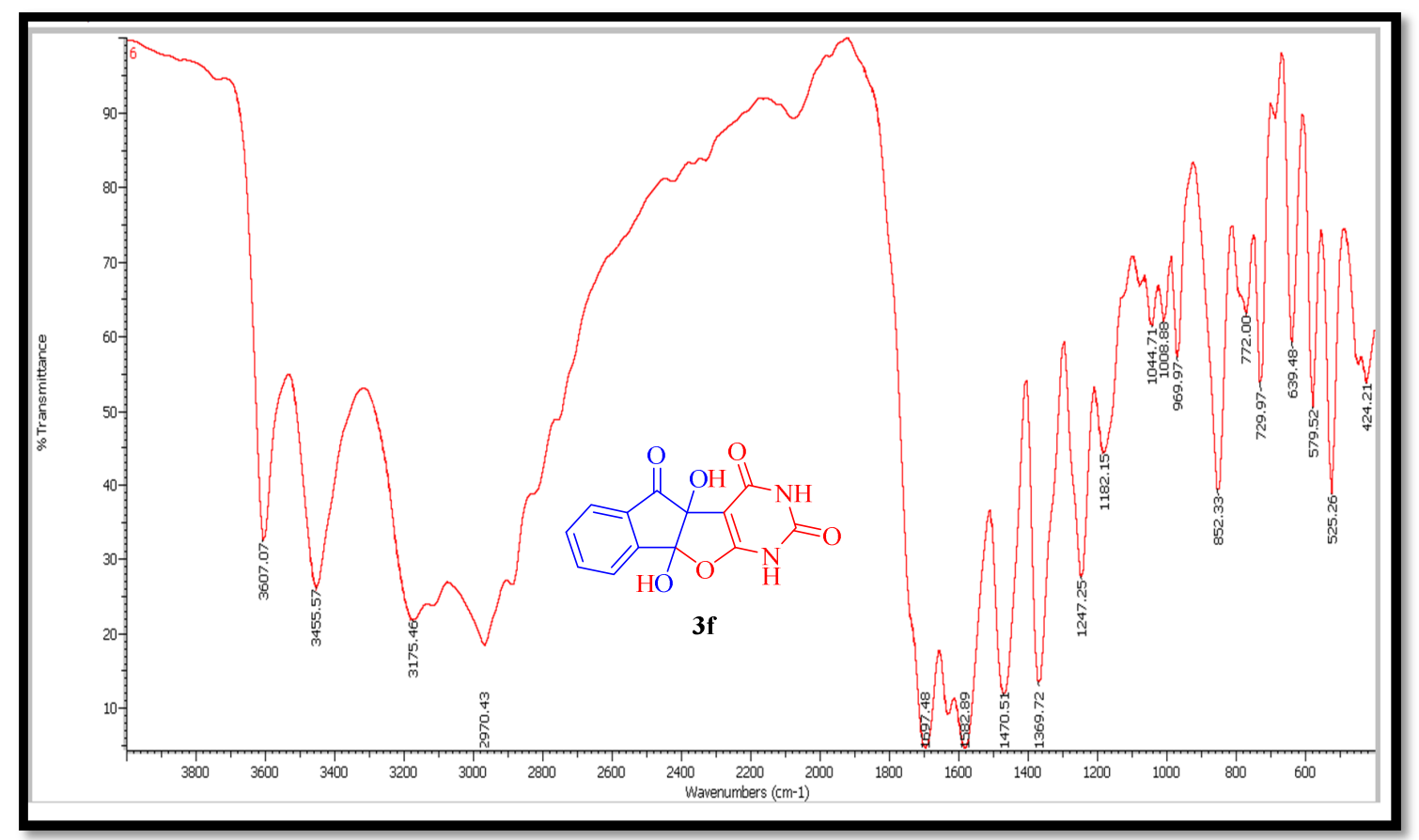

Fig. S16. Mass spectrum of compound $3 f$.

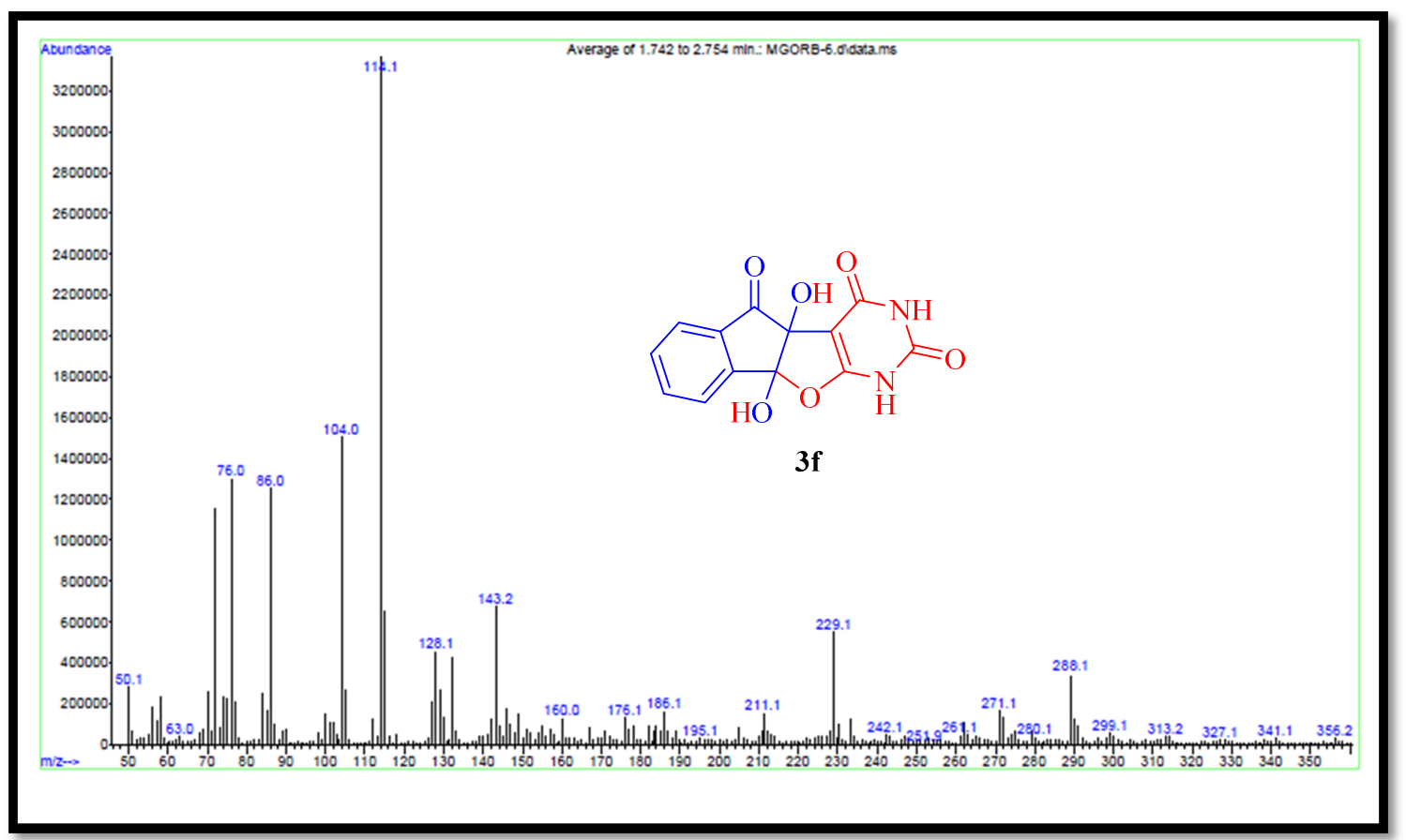


4b,9b-Dihydroxy-2-thioxo-2,3,4b,9b-tetrahydro-4H-indeno[2',1':4,5]furo[2,3-d]pyrimidine-4,5(1H)-dione (3g)

Fig. S17. ${ }^{1} \mathrm{H}$ NMR spectrum $\left(300 \mathrm{MHz}, \mathrm{DMSO}-d_{6}\right)$ of compound $\mathbf{3 g}$.

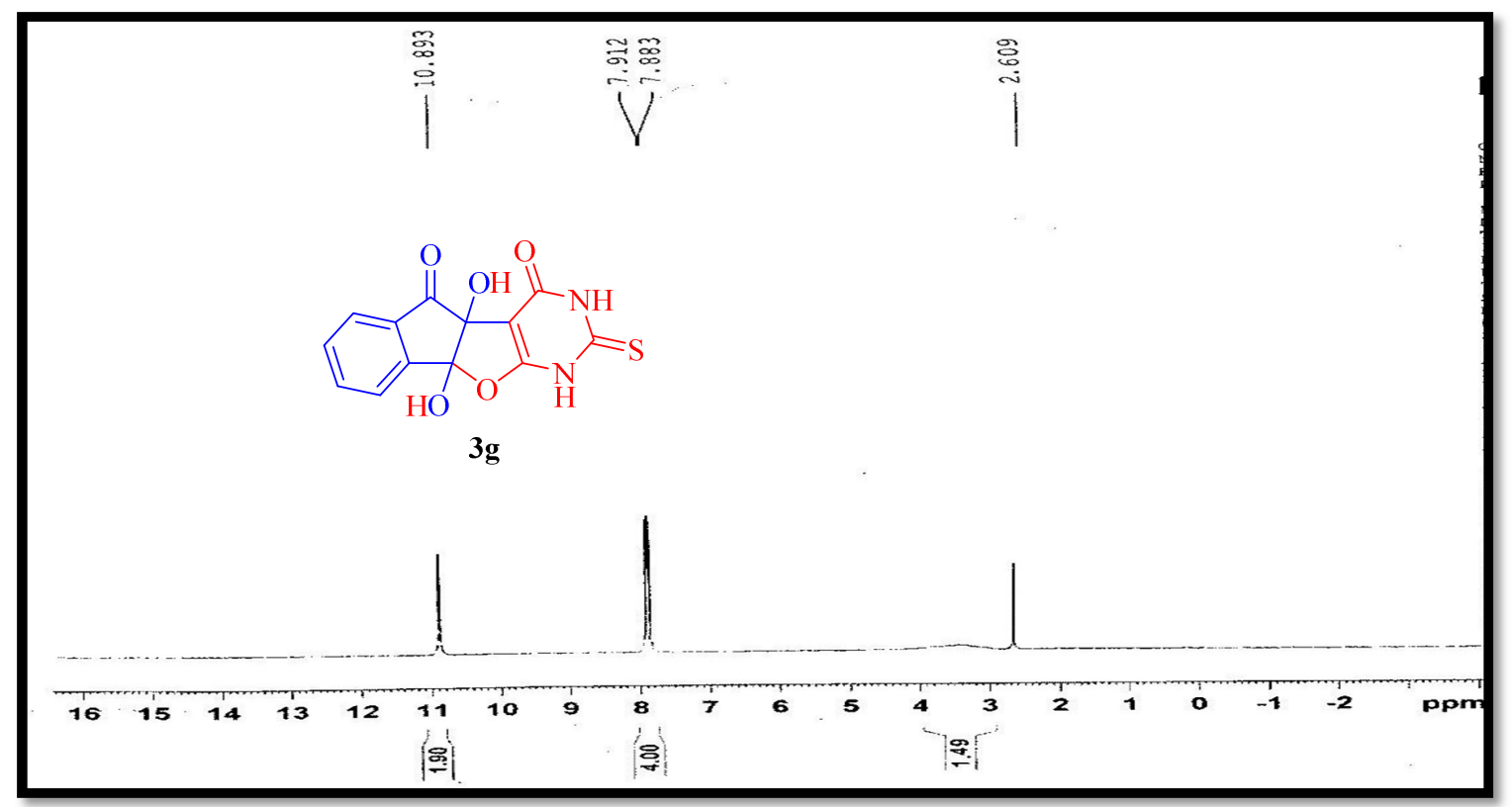

Fig. S18. ${ }^{13} \mathrm{C}$ NMR spectrum (75.5 MHz, DMSO- $\left.d_{6}\right)$ of compound 3g.

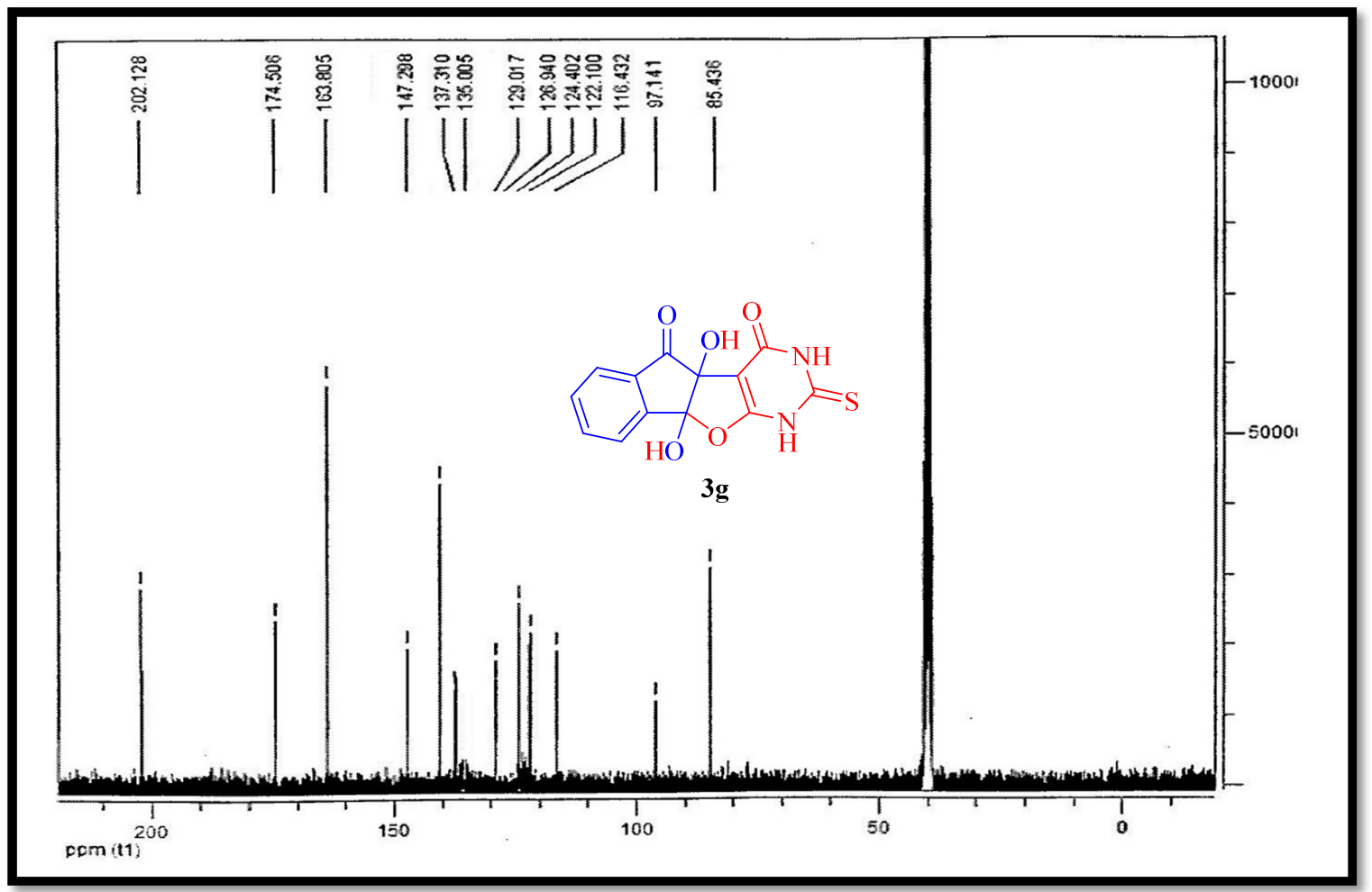


Fig. S19. IR spectrum ( $\mathrm{KBr})$ of compound 3g.

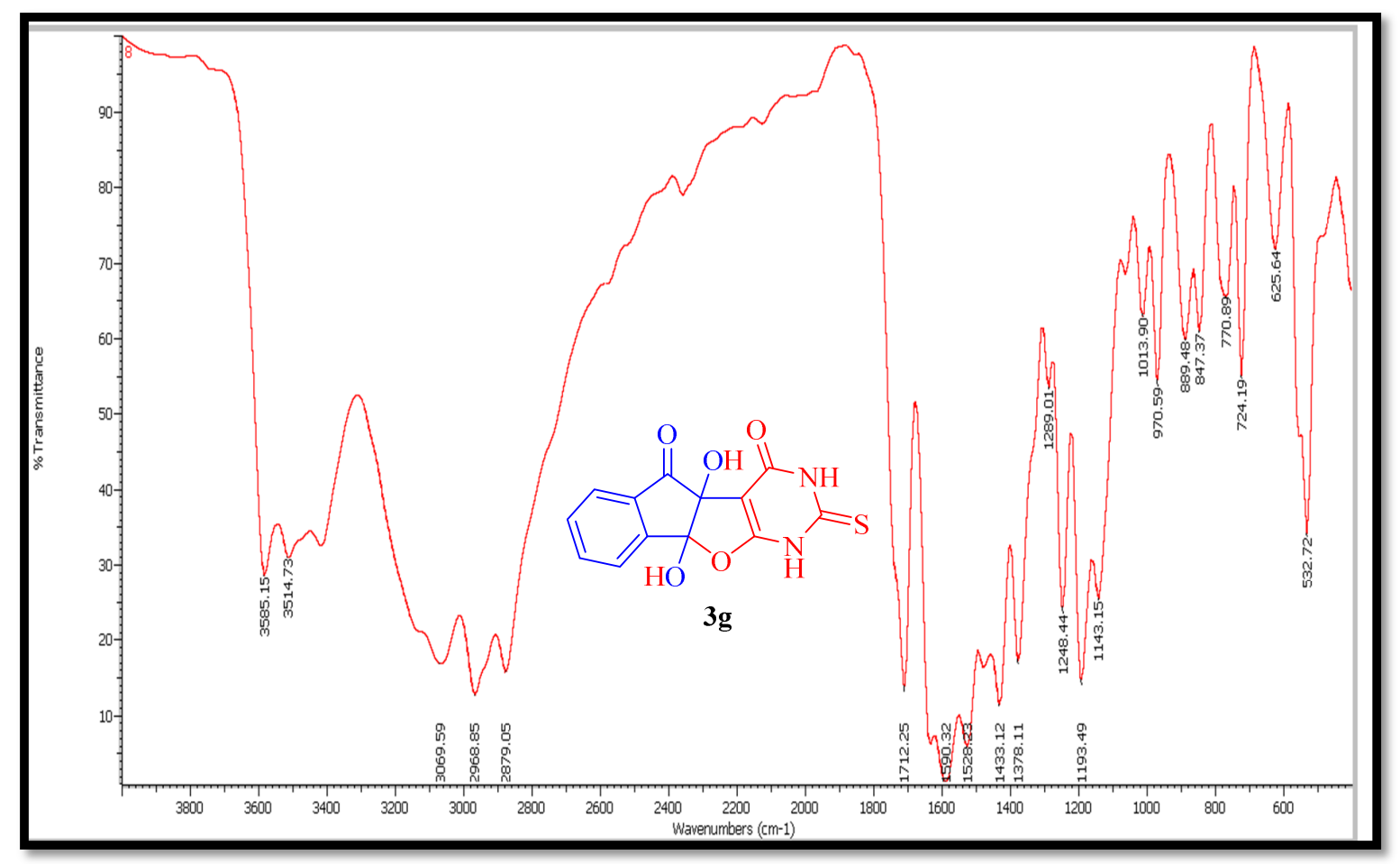

Fig. S20. Mass spectrum of compound 3g.

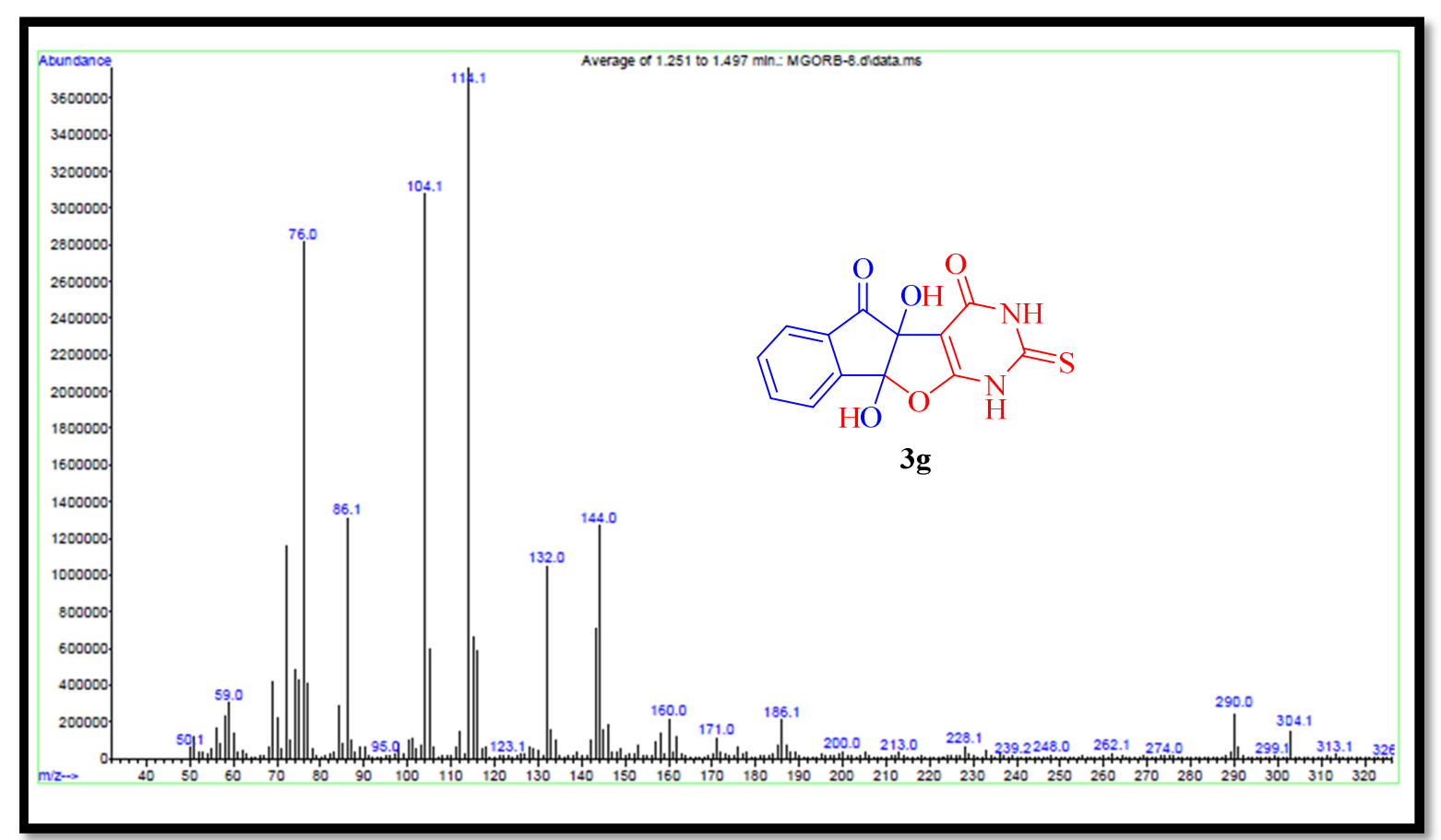


4b,9b-Dihydroxy-1,3-dimethyl-4b,9b-dihydro-2H-indeno[2',1':4,5]furo[2,3-d]pyrimidine2,4,5(1H,3H)-trione (3h)

Fig. S21. ${ }^{1} \mathrm{H}$ NMR spectrum $\left(300 \mathrm{MHz}, \mathrm{CDCl}_{3}\right)$ of compound $\mathbf{3 h}$.

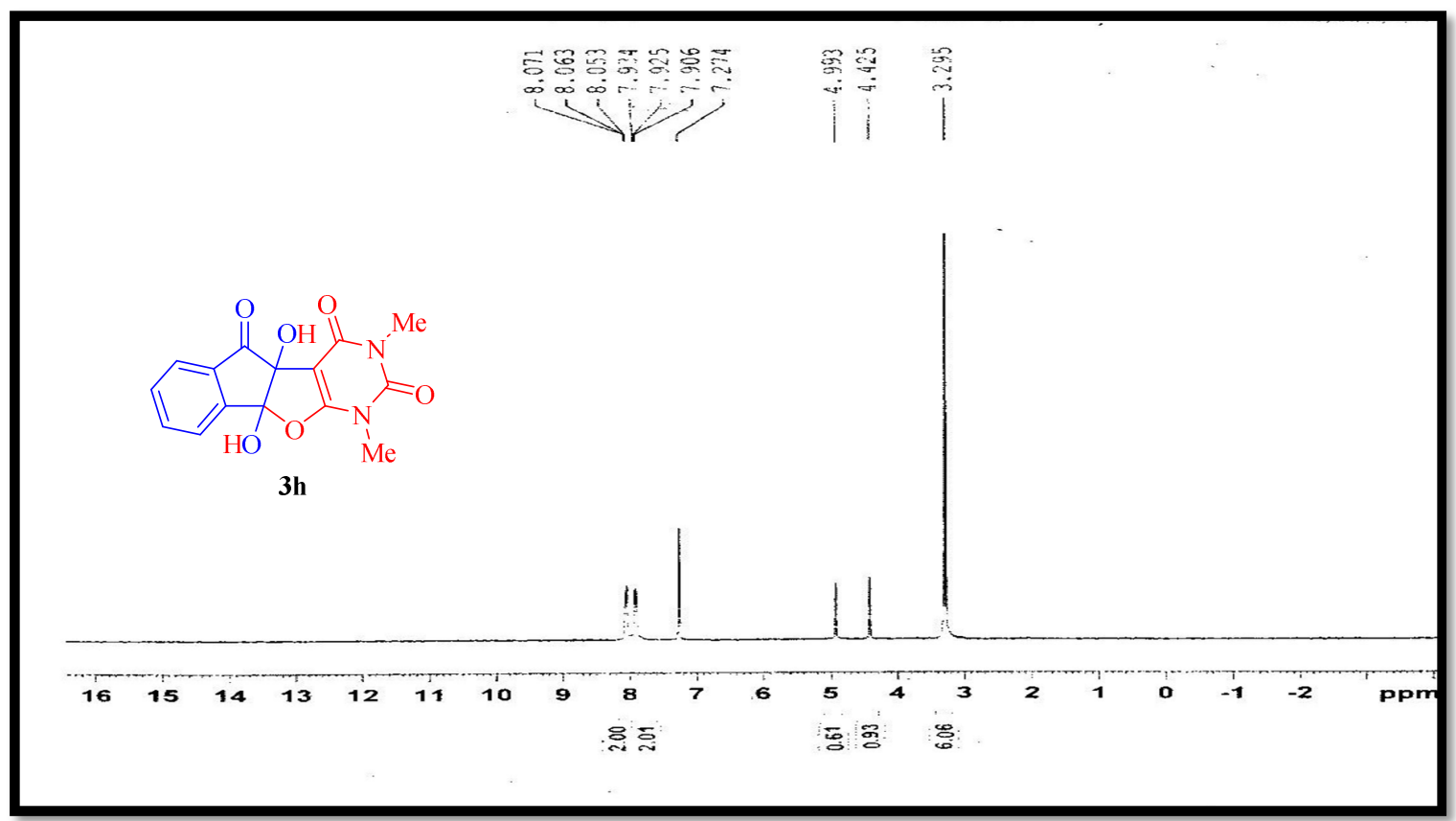

Fig. S22. ${ }^{13} \mathrm{C}$ NMR spectrum $\left(75.5 \mathrm{MHz}, \mathrm{CDCl}_{3}\right)$ of compound $\mathbf{3 h}$.

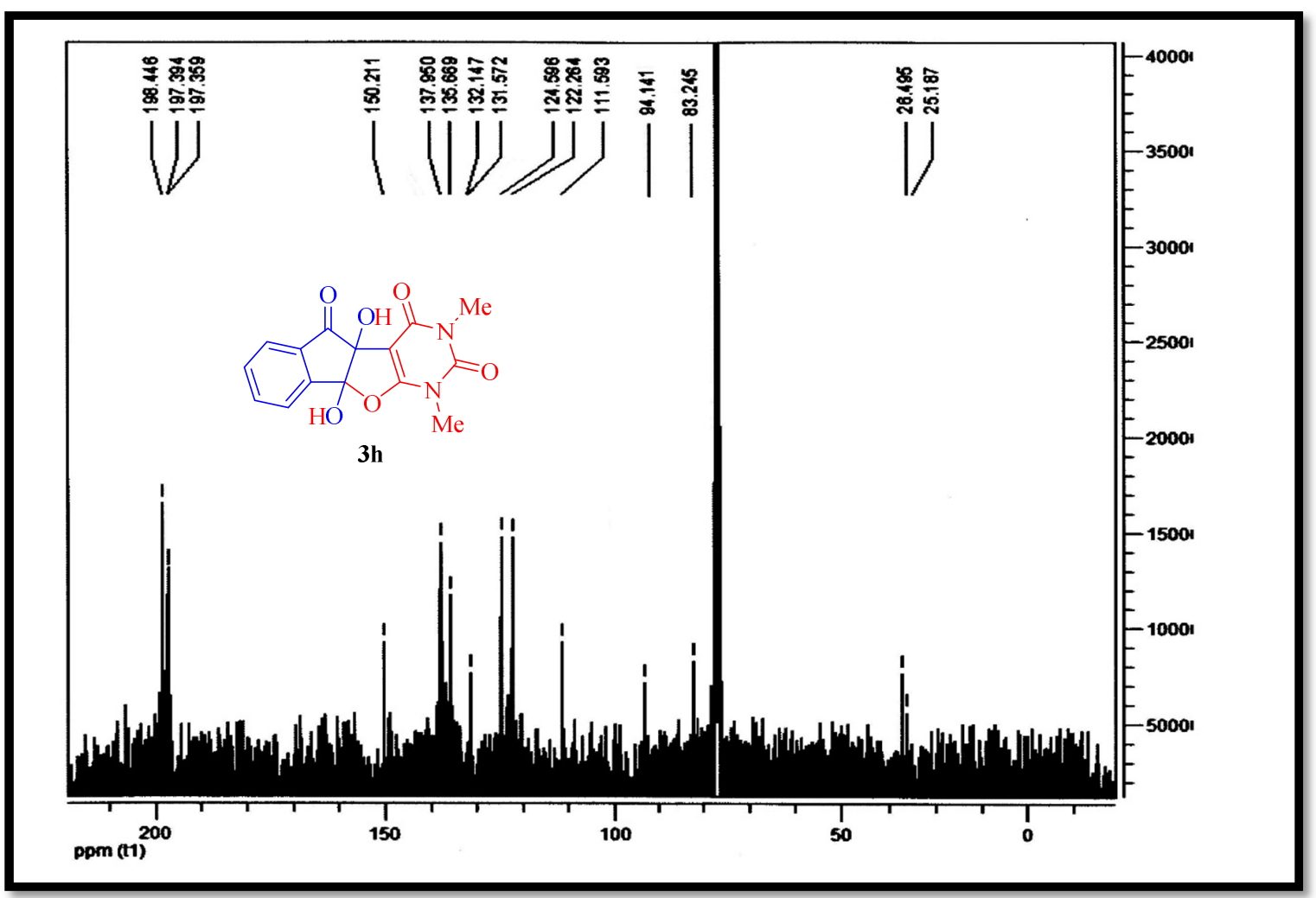


Fig. S23. IR spectrum (KBr) of compound $\mathbf{3 h}$.

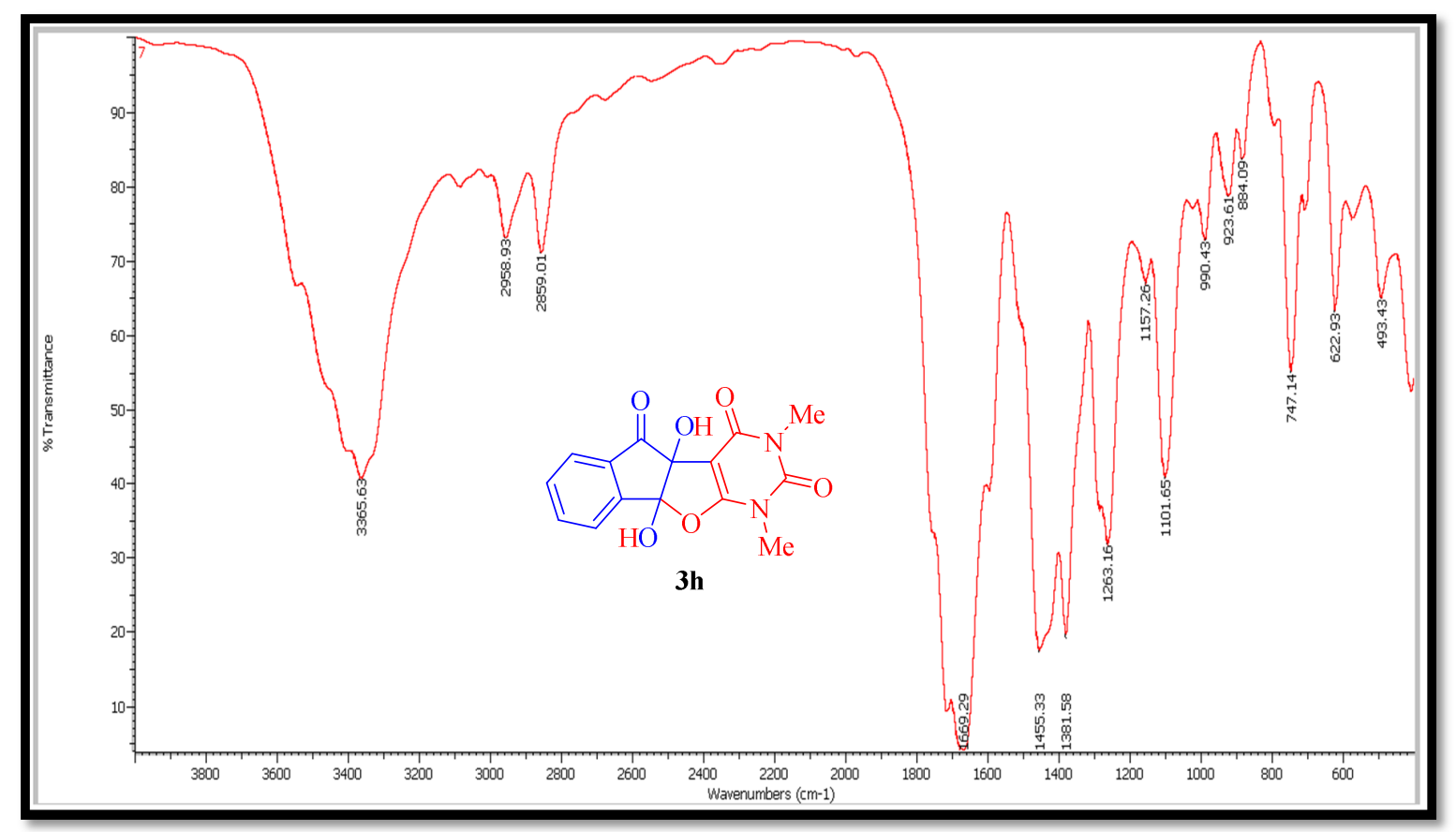

Fig. S24. Mass spectrum of compound $\mathbf{3 h}$.

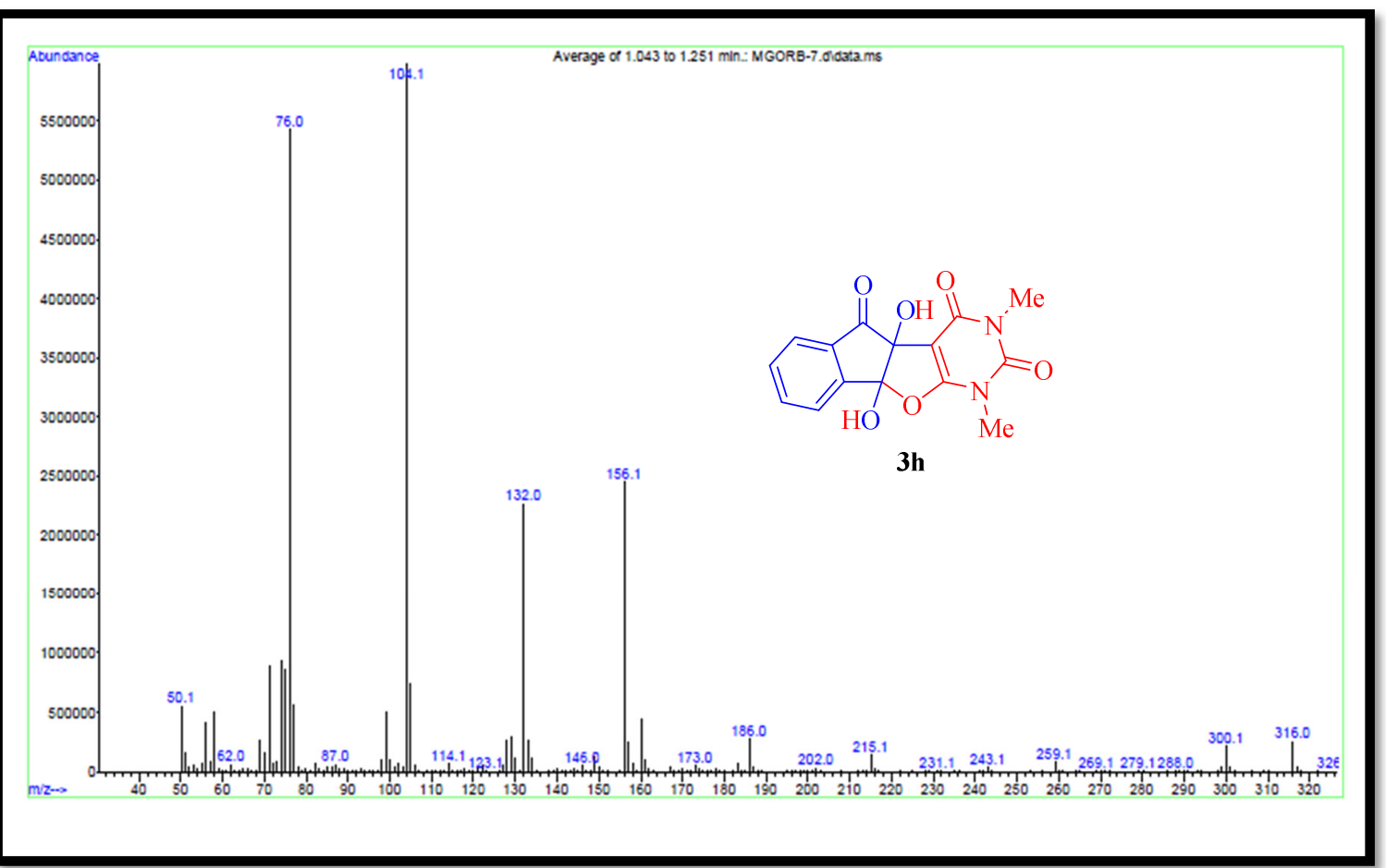


4b,10b-Dihydroxy-4b,10b-dihydrodiindeno[1,2-b:2',1'-d] furan-10,11-dione (3i)

Fig. S25. ${ }^{1} \mathrm{H}$ NMR spectrum $\left(300 \mathrm{MHz}, \mathrm{DMSO}-d_{6}\right)$ of compound $3 \mathbf{i}$.

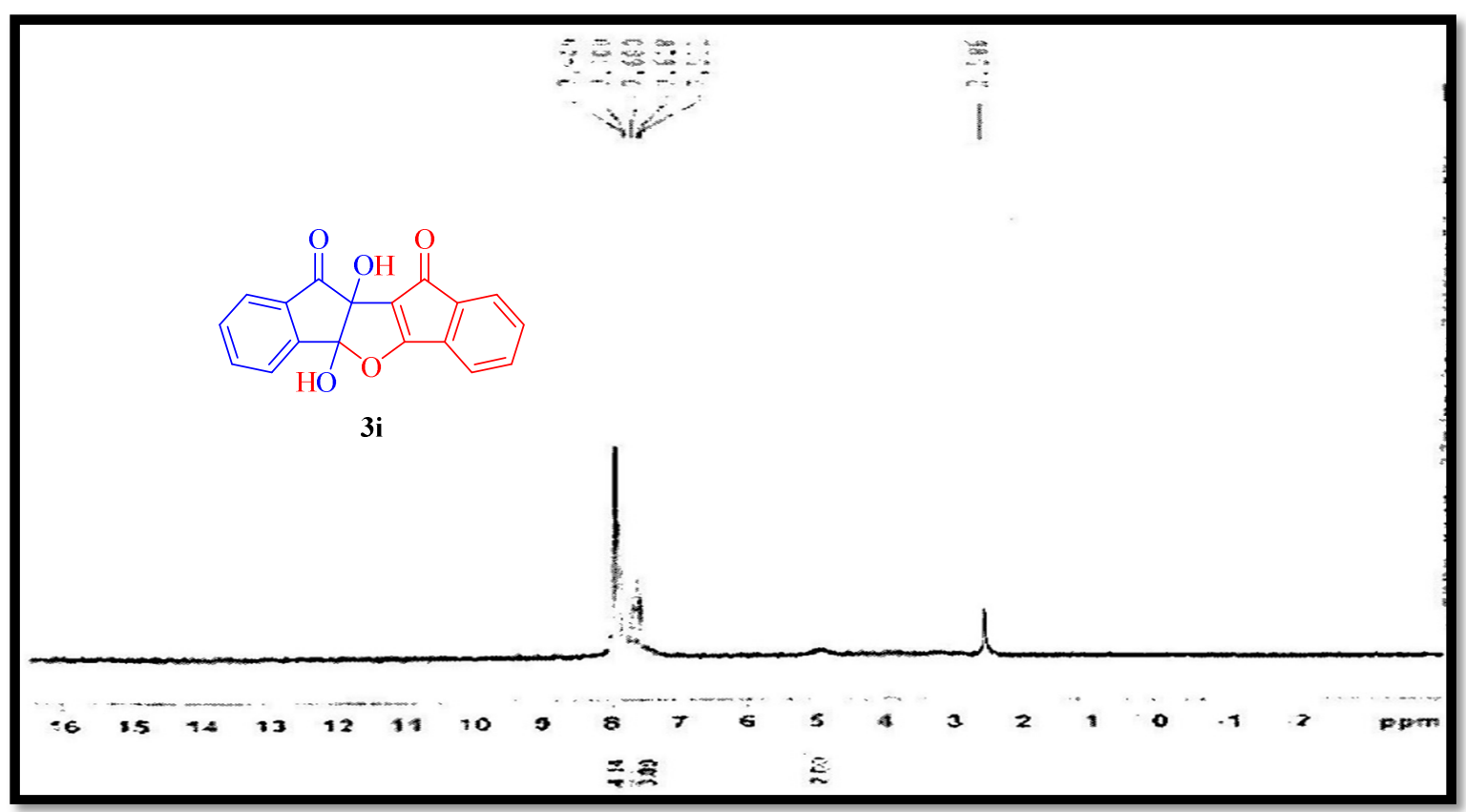

Fig. S26. ${ }^{13} \mathrm{C}$ NMR spectrum (75.5 MHz, DMSO- $\left.d_{6}\right)$ of compound $3 \mathbf{i}$.

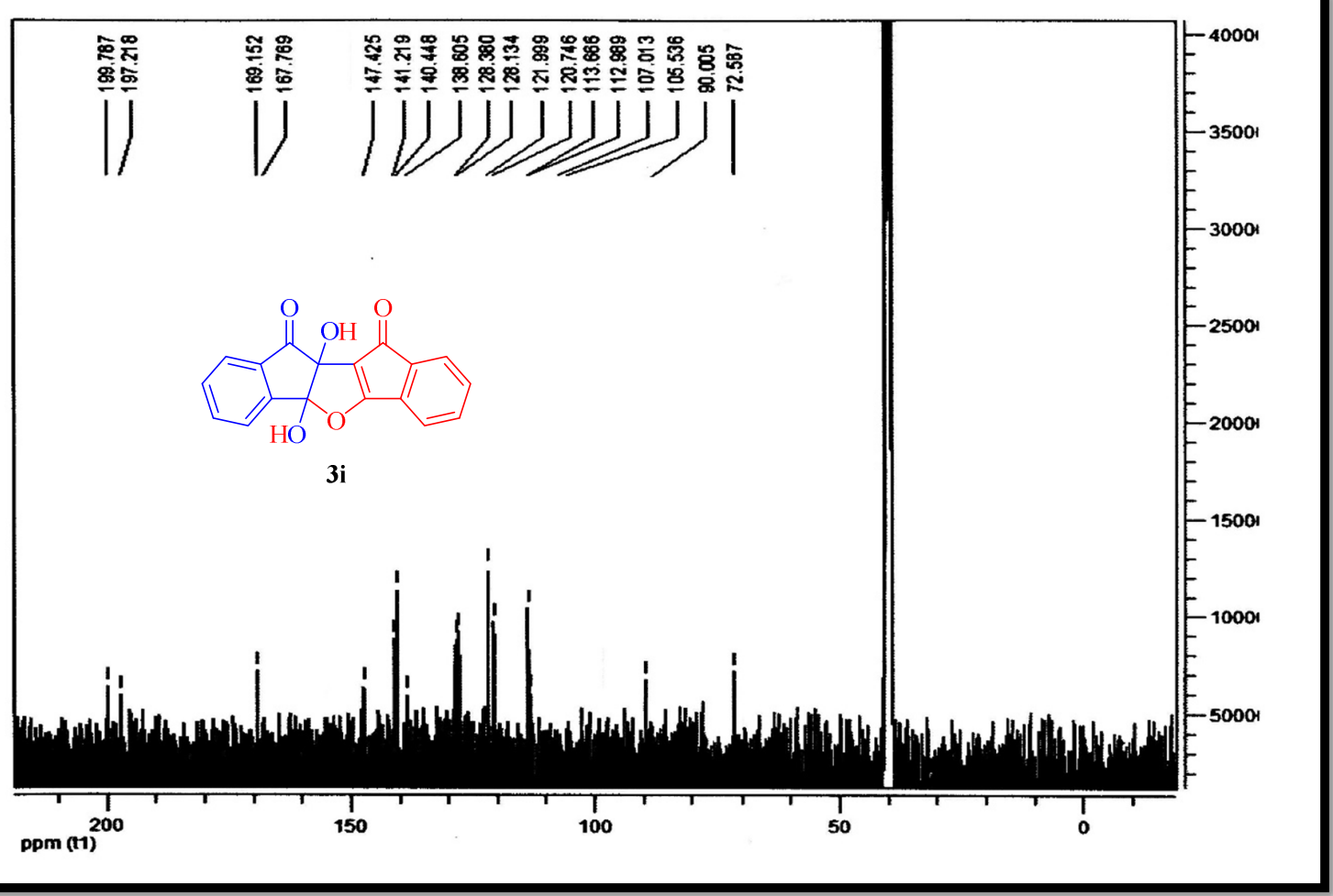


Fig. S27. IR spectrum (KBr) of compound 3i.

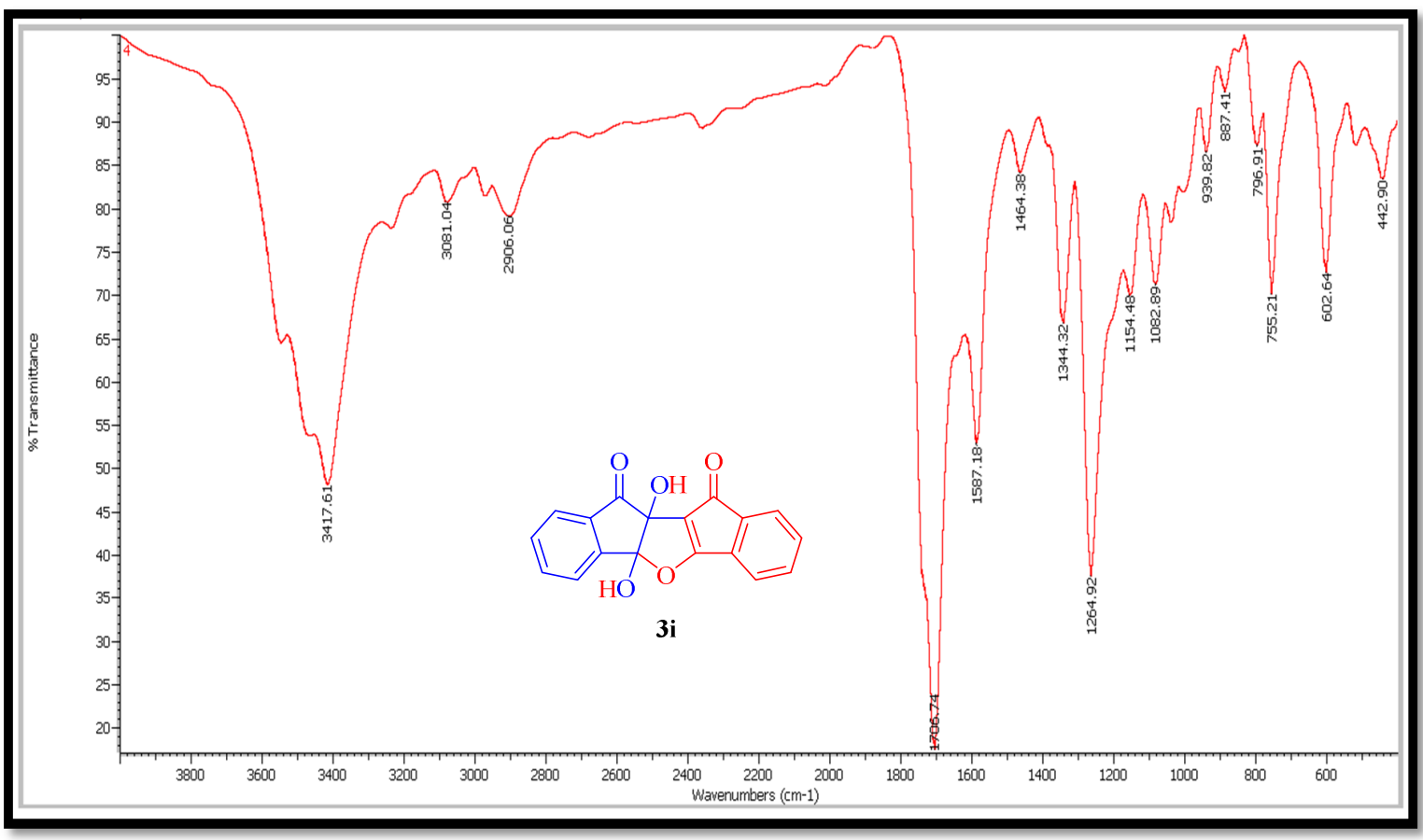

Fig. S28. Mass spectrum of compound 3i.

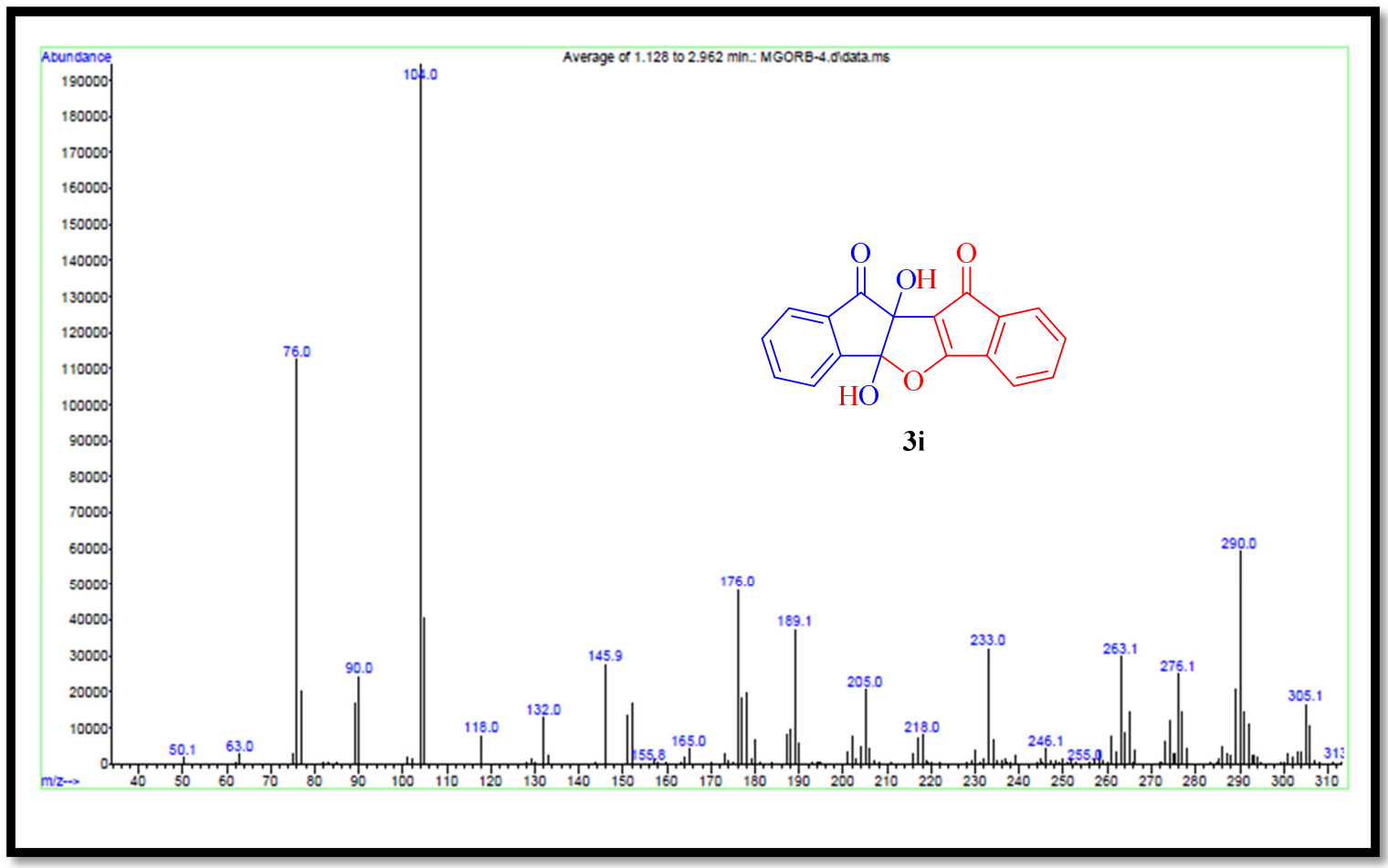

